
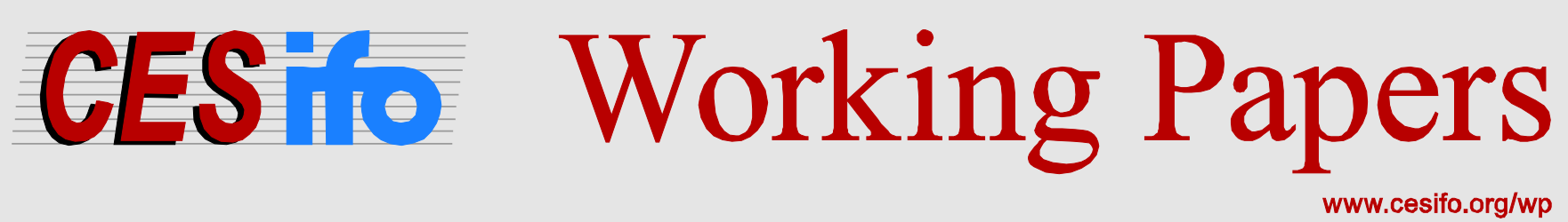

\title{
Successful Fiscal Adjustments Does Choice of Fiscal Instrument Matter?
}

\author{
Steinar Holden \\ Nina Larsson Midthjell
}

\author{
CESIFO WORKING PAPER NO. 4456 \\ CAtegory 6: Fiscal Policy, Macroeconomics and Growth \\ OCTOBER 2013
}

An electronic version of the paper may be downloaded

- from the SSRN website:

- from the RePEc website:

- from the CESifo website:

WWW.SSRN.com

www.RePEc.org

www.CESifo-group.org/wp

\section{CESifo}




\title{
Successful Fiscal Adjustments Does Choice of Fiscal Instrument Matter?
}

\begin{abstract}
We examine fiscal adjustment episodes in 24 OECD countries in order to find how austerity affects debt and growth, and whether the choice of fiscal instrument matters for the results. Influential existing studies argue that spending cuts are more likely to successfully reduce debt and enhance economic growth than tax increases. Our main innovations over these studies are to better account for initial conditions and to employ a novel and more precise measure of actual changes in fiscal policy. We find that whether a fiscal adjustment is successful in reducing debt depends on whether the adjustment was sufficiently large to remove the budget deficit. We find no indication that it matters whether the adjustment is achieved via spending cuts or tax increases, and this conclusion holds also for the effect on economic growth.
\end{abstract}

JEL-Code: H200, H300, H500, H620.

Keywords: fiscal adjustment, fiscal consolidation.

\author{
Steinar Holden \\ Department of Economics \\ University of Oslo / Norway \\ steinar.holden@econ.uio.no
}

\author{
Nina Larsson Midthjell \\ Department of Economics \\ University of Oslo \& Norges Bank \\ Oslo / Norway \\ nina-larsson.midthjell@norges-bank.no
}

September 25, 2013

We are in particular grateful to Erik Biørn, Gisle Natvik and Asbjørn Rødseth for valuable comments. In addition, this paper has benefitted from comments from participants at the GRASP 2012 Bocconi Workshop on Fiscal Policy and Growth and the Seattle WEAI 2013 conference, as well as seminar participants at the Federal Reserve Bank of Minneapolis, the IMF Fiscal Affairs Department, Norges Bank, Statistics Norway and the University of Oslo. Any errors are the authors' own responsibility. The paper is part of the research activities at the centre of Equality, Social Organization, and Performance (ESOP) at the Department of Economics at the University of Oslo. ESOP is supported by the Research Council of Norway. Nina Larsson Midthjell thanks the Federal Reserve Bank of Minneapolis and University of Oslo, where most of this paper was written. The views expressed in this paper are those of the authors only and should not be attributed to Norges Bank. 


\section{Introduction}

In the aftermath of the Great Recession, austerity measures have been implemented in many OECD countries to deal with large budget deficits and increasing debt levels resulting partly from considerable fiscal stimulus. Given the current weak state of the economy, a main challenge is to reduce deficit and debt levels without stalling the badly needed recovery. A widespread view among observers and policy makers is that spending cuts are more likely to be successful in reducing debt and enhancing economic growth than tax increases. This view has been advocated forcefully by Alesina and Perotti (1995), and in a more recent follow-up study by Alesina and Ardagna (2010). These studies have received a lot of attention. ${ }^{1}$ In particular, they have been used as reference for this view in important settings by policy makers in Europe and the US. ${ }^{2}$, by popular commentators (e.g. Brooks (2010), as well as influential text books like Romer (2012), where page 604 reads: "Alesina and Perotti (1996) present evidence that deficit reductions coming from cuts in government employment and transfers are much more likely to be maintained than reductions coming from tax increases (...)" ${ }^{3}$ Moreover, in its World Economic Outlook, October 2010 edition, chapter 3, the IMF describe these and related studies as "extremely influential in the debate regarding the consequences of fiscal adjustment", with a footnote saying that "Many studies have followed the Alesina and Perotti (1995) methodology (...)".

The strong impact of Alesina and Perotti (1995) and Alesina and Ardagna (2010)

\footnotetext{
${ }^{1}$ In Google Scholar the two studies have 822 and 249 citations respectively.

${ }^{2}$ For example, in a UK HM Treasury presentation of international examples of spending consolidations, it is concluded that "There is broad agreement in the literature that spending restraint is more likely to generate lasting fiscal consolidation and better economic performance than tax increases", with a reference to Alesina and Perotti (1995), see UK HM Treasury (2009). In the ECB Monthly Bulletin, June 2010 edition, page 85, it is concluded that "Overall, it appears that expenditure-based fiscal consolidations are more successful and have more beneficial effects on long-run economic growth than revenue-based ones", with reference to the Alesina presentation Fiscal adjustments: Lessons from recent history (Ecofin meeting in Madrid on 15 April, 2010) , for which a key reference is Alesina and Ardagna (2010). In a testimony at hearings on impediments to job creation, Ways and Means Committee, House of Representatives, March 30, 2011, Andrew G. Biggs, American Enterprise Institute, concluded that "countries that (...) reduced spending were far more likely to reduce their debt than countries whose budget-balancing strategies depended upon higher taxes", based on several studies using variations of the Alesina and Ardagna (2010)-method, including Biggs' own approach, see Biggs (2011).

${ }^{3}$ More precisely, Romer refers to a 1997 version of the same paper.
} 
(henceforth AAP) reflects that these studies undertake a direct and intuitive comparison of episodes of fiscal adjustments, and it appears to be a robust finding that spending cuts are more likely than tax increases to succeed in reducing debt, with a possibly expansionary impact on growth. In this paper we argue that this result is not robust. AAP use an imprecise measure of changes in fiscal policy due to insufficient cyclical adjustment, making their results vulnerable to reverse causality. When we repeat the analysis of Alesina and Ardagna $(2010)^{4}$ with a measure of changes in fiscal policy designed to avoid reverse causality, we find little difference between the fiscal instruments. Unsuccessful episodes are characterized by slightly larger cuts in spending and somewhat larger tax increases than successful episodes, but the difference is small. The crucial difference between successful and unsuccessful fiscal adjustments is much more straightforward: whether the budget deficit was removed. Unsurprisingly, fiscal adjustments that were too small to remove the budget deficit were also less likely to achieve a notable reduction in debt.

After reviewing the findings of AAP, we proceed with a similar analysis based on a more precise measure of fiscal policy, using a fiscal indicator suggested in Holden and Midthjell (2013). This indicator links fiscal adjustments directly to changes in the main tax bases, involving a more precise measurement of fiscal policy changes. The main picture is unchanged: The difference in the use of fiscal instruments between successful and unsuccessful adjustments is small, and the key difference is whether the budget deficit is actually removed. Again, the message is clear: to reduce debt, one should adjust sufficiently to remove the budget deficit. Thus, the results cannot be used to argue against cutting budget deficits by raising taxes, as Alesina and Ardagna (2010) do.

Our study is not the first to discuss or criticize the approach and findings of AAP. Jayadev and Konczal (2010) argue that the episodes where the fiscal adjustments were successful are characterized by strong growth in the economy in the years prior to the adjustment. In what is probably the most comprehensive discussion, IMF (2010) argue that the results of AAP are problematic due to measurement errors

\footnotetext{
${ }^{4}$ We focus on the most recent study due to data availability and proximity in time.
} 
and erroneous control for policy motivation: The cyclical adjustment method is imperfect, implying for example that it fails to remove swings in tax revenue due to asset price movements, so that the analysis downplays contractionary effects and overstate expansionary effects. Furthermore, selecting adjustment episodes based on observed changes in the budget balance ignores the motivation behind the fiscal actions, involving a risk of missing cases of consolidation followed by adverse shocks. Instead, IMF (2010) advocate the use of data for fiscal actions motivated by deficit reduction, derived from a thorough examination of accounts and reports to learn what types of fiscal policy the countries actually conducted. The idea follows the "narrative approach" used by Romer and Romer (2010) on the identification of tax changes; IMF (2010) refer to it as the "action-based approach". Perotti (2012) evaluates the critique of AAP by the IMF, and concludes that it is "correct in principle". However, our study raises other fundamental problems with the AAP studies, and we discuss other measurement problems than the ones discussed by IMF (2010). None of these studies, nor any other to the best of our knowledge, explore the points about reverse causality and whether the budget deficit is removed, which are the key arguments of our paper.

The low growth and increasing public debt in many OECD countries has led to a virtual explosion of research on the effect of fiscal policy. The new research uses a number of different statistical methods and in most cases also different data sets than AAP, and also our study. Furthermore, the novel studies show opposing results for choice of fiscal instrument, with some finding that spending cuts have less negative effect on growth than tax rises, while other studies find evidence for the opposite conclusion. ${ }^{5}$ IMF (2010) find that spending-based adustments are less contractionary than tax-based adjustments, but emphasize that a key reason for this result might be that spending-based adjustments typically benefit from a large dose of monetary stimulus. Using partly the same methods as in their earlier paper, but somewhat different definitions, Alesina and Ardagna (2012) once more

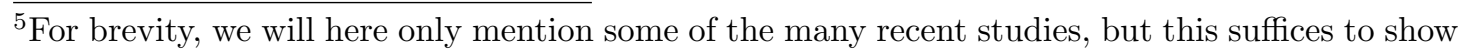
that the results are mixed.
} 
report evidence in favour of spending cuts. ${ }^{6}$ Alesina, Favero and Giavazzi (2012) use the data set provided by Devries et al. (2011) as a basis for computing impulse response functions for 15 OECD countries. They find that spending-based fiscal consolidations are associated with mild and short-lived recessions, while tax-based adjustments are associated with prolonged and deep recessions. In contrast, Batini et al. (2012) use a regime-dependent VAR for the US, Japan and Europe, building on the framework of Auerbach and Gorodnichenko (2012), and find that the expenditure-multiplier is much larger in downturns than in booms, and also much larger than the tax multiplier. Caldara and Kamps (2012) explore identification schemes for structural vector autoregression (SVAR), and their results for the US suggest that the probability that the tax multiplier is larger than the spending multiplier is below 0.5 at all horizons.

While the use of action-based data sets has been an important innovation for the study of fiscal policy effects, it is not without problems. Perotti (2012) provides examples showing that the data might be subject to important measurement errors, as governments quite often will reverse spending cuts announced in the budget in subsequent supplementary budgets. Furthermore, by explicitly including only actions which are motivated by debt reduction, and thus omitting fiscal actions for stabilization purposes, one may obtain an inaccurate picture of the actual fiscal stance. Another problem is that it might be hard to assess the true intention of a policy change solely by reading policy documents. For example, even if a consolidation is correctly viewed to be motivated by a desire to reduce debt, it is not clear that it would actually have been undertaken if the economy went into a recession. In this case an endogeneity problem would remain, involving a potential

\footnotetext{
${ }^{6}$ The evidence in Alesina and Ardagna (2012) for this conclusion is however subject to similar problems as those of Alesina and Ardagna (2010). While successful fiscal adjustments have much higher share of spending cuts than unsuccessful (Table 5a), the successful adjustments are also much larger, with an average reduction of the deficit to GDP of 6.3 percentage point for successful adjustments and 3.9 percentage points for unsuccessful. Initial conditions are also more favorable in the successful adjustments, with growth in GDP of 2.4 percent as compared to 1.5 in unsuccessful (Table 6). In the alternative comparison of Alesina and Ardagna (2012), based on the action-based Devries et al. (2011) data from the IMF, the successful adjustments are also much larger, 4.8 percent of GDP as compared to 2.7 percent of GDP. Furthermore, on these data there is no difference in the spending share between successful and unsuccessful adjustments, with 61.5 percent for successful and 62 percent for unsuccessful (Table 14a). Thus, as shown in Midthjell (2013), the robust conclusion seems to be that adjustments are more likely to succeed if they are large and undertaken under favorable initial conditions.
} 
bias in the results.

In light of the mixed results in the recent literature, and the prominence, clarity and intuitive appeal of the method and results of AAP, these studies are likely to still have considerable influence on the perceptions of economists, commentators and policy makers. ${ }^{7}$ If their results are biased, as we argue they are, it is important to make a strong case against the intuitive, yet misleading results.

The remainder of the paper is organized as follows: in section 2, we review the results of Alesina and Ardagna (2010) and compare them with results from a modification to their approach that is less subject to reverse causality. In section 3 , we conduct a similar analysis with a more precise measure of changes in fiscal policy. Section 4 concludes.

\section{The effect of fiscal adjustments}

The aim of this paper is to evaluate the effect of fiscal adjustments, and in particular compare the effect of cuts in spending as opposed to tax increases. While the problem is simple, it involves a number of empirical challenges. First, one must identify fiscal adjustments, and distinguish between changes in spending and changes in taxes. The difficulty here lies in the fact that both public expenditure and tax revenues will be affected by changes in the economy as well as changes in policy, so it is necessary to distinguish between these two sources. Second, one must identify the effects of the fiscal adjustments. Thus, one must distinguish the effect of the adjustment itself from the effect of initial conditions as well as other exogenous changes that may take place during the adjustment. This may be difficult, not least because the change in budgetary components might be endogenous,

\footnotetext{
${ }^{7} \mathrm{~A}$ recent example indicates the influence from these studies. On 4 March, 2013, the independent but influential Washington thinktank, The Tax Foundation, adviced in favour of spending cuts with reference to Alesina and Ardagna (2010) as empirical evidence: "A better option, according to empirical evidence, is to replace the sequester with cuts to mandatory spending. This may even boost GDP in the short term as well as the long term. The worst option of all, according to most empirical studies, is to replace the sequester in part or whole with higher income taxes. The vast majority of countries who have successfully reduced their debt have done so by reducing spending rather than increasing taxes".
} 
i.e. caused by changes in the economy, not by changes in fiscal policy.

In this paper, we follow Alesina and Perotti (1995) and Alesina and Ardagna (2010) and focus on large adjustment episodes, without controlling for policy motivation. As discussed in the introduction, this approach may potentially bias the results, as it might be difficult to distinguish policy effects from shocks that might have influenced the policy decision. However, as pointed out by Alesina and Perotti (1995), this may be less problematic when the aim is to compare the effect of spending cuts and tax increases: if the noise in the selection of episodes does not involve a systematic bias between the different types of fiscal instrument, the comparison of the two types of instrument will be valid even if the adjustment decision itself is endogenous. We return to this issue below.

\subsection{The AAP approach}

The aim of this section is to justify our claim that the results in Alesina and Ardagna (2010) for successful debt reduction are driven by differences in the size of the budget deficit, not by choice of a specific fiscal instrument. ${ }^{8}$ Alesina and Ardagna (2010) consider 21 OECD countries over the period 1970 to 2007. Within this data set, they consider years of fiscal adjustment, defined as years in which the cyclically adjusted primary balance ratio to GDP improves by at least 1.5 percentage points. The cyclical adjustment is performed using the method suggested by Blanchard (1990), usually referred to as the Blanchard Fiscal Impulse (BFI), where the budget components are adjusted separately for the effect of the change in the unemployment rate. More precisely, each of the tax components as well as public transfers, measured as a ratio to GDP, is regressed on the unemployment rate and a time trend. The estimated coefficients and residuals from this regression are then used to predict what the value of the fiscal variable as a share of GDP in year $t$ would have been if the unemployment rate were the same as in year $t-1$. The cyclically adjusted value of the change in the fiscal variable is the difference between this predicted value and the actual value of the fiscal variable as a share

${ }^{8}$ The approach and main results are similar to those of Alesina and Perotti (1995), which will be discussed briefly at the end of this section. 
to GDP in year t-1.

Alesina and Ardagna (2010) find 107 years of fiscal adjustments, which are reduced to 83 fiscal adjustment episodes because consecutive adjustment years are considered as one episode. The authors seek to examine two effects of the fiscal adjustments: (i) whether the adjustment is successful in reducing debt-to-GDP, and (ii) whether the adjustment has an expansionary effect on growth.

First, consider the effect of the adjustment on debt, where Alesina and Ardagna (2010) define a fiscal adjustment episode as successful if the cumulative reduction in the debt-to-GDP ratio in the initial year of adjustment and two years forward is greater than 4.5 percentage points (the value of the 25 th percentile of the same variable's empirical density in all episodes of fiscal adjustments). This definition selects 17 successful episodes. Table 1, which is a copy of table 5 in Alesina and Ardagna (2010), reports their main results. The table distinguishes between successful and unsuccessful adjustment episodes, and then shows the means of fiscal variables for three time periods, which are the average of the two years before the adjustment, years $T-2$ and $T-1$, the initial year of adjustment, year $T$, and the average of the two years after the initial year of adjustment, years $T+1$ and $T+2$. We observe that in successful episodes, the primary expenditure to GDP ratio is reduced on average by 1.95 percentage points from before to after the adjustment, cf. column (c)-(a), while the total revenue to GDP ratio is reduced by 0.51 percentage points. In contrast, in unsuccessful adjustments, primary expenditure to GDP only drops 0.72 percentage points, whereas total revenue to GDP increases by 1.41 percentage points. Alesina and Ardagna (2010) conclude that "successful fiscal adjustments are completely based on spending cuts accompanied by modest tax cuts".

We argue that this conclusion is problematic for two reasons in particular: (i) It fails to include other important explanatory factors, and (ii) it is based on imprecise identification of fiscal policy changes. Let us first consider other important explanatory factors. The change in the debt-to-GDP ratio in year $t$ can be written 
as:

$$
\Delta\left(\frac{D}{Y}\right)_{t}=-\Delta\left(\frac{B^{p}}{Y}\right)_{t}-\left(\left(\frac{B^{p}}{Y}\right)_{t-1}-\frac{i D}{Y_{t-1}}\right)-\frac{\Delta Y_{t}}{Y_{t}} \frac{D_{t-1}}{Y_{t-1}}+\left(\frac{\Delta i D}{Y}\right)_{t}
$$

where $\Delta\left(\frac{D}{Y}\right)_{t}$ is the change in the debt-to-GDP ratio from period $t-1$ to period $t$, measured at the end of the year, $\Delta$ is the first difference operator, $-B_{t}^{p}=-\left(T_{t}-\right.$ $\left.G_{t}\right)$ is the primary budget deficit, $T_{t}$ is primary revenue, $G_{t}$ is primary expenditure, and $i D_{t}$ is net interest payments, all in nominal terms. ${ }^{9}$ Alesina and Ardagna (2010) concentrate on the first component on the right handside of equation (1), the change in the cyclically adjusted primary budget deficit, but they essentially neglect the two following terms, the initial total deficit, $-\left[\left(\frac{B^{p}}{Y}\right)_{t-1}-\frac{i D}{Y}{ }_{t-1}\right]$, and the effect of growth in GDP. If we study table 1 more closely, we note that the initial deficit plays an important role. For successful adjustments, the total deficit was 2.5 percent of GDP on average in the two years prior to the adjustment (i.e. in years $T-1$ and $T-2$ ), implying that the adjustment essentially reduced the deficit, down to an average of 0.29 percent in year $T$. In contrast, for the unsuccessful adjustments, the total prior deficit was on average much larger, 5.6 percent of GDP (average of years $T-2$ and $T-1$ ), and a large deficit remained also after the adjustment, with an average of 3.77 percent of GDP in year $T$ and 3.69 percent on average in years $T+1$ and $T+2$. Given the large initial deficit and the fact that the adjustments on average were too small to ensure a positive budget balance, it is hardly surprising that these adjustments failed to reduce the debt-to-GDP ratio.

\footnotetext{
${ }^{9}$ In addition, there may be important stock-flow adjustments that affect the evolution of the debt without being part of the calculated deficit, see Joumard et al. (2008). Furthermore, we follow the literature and consider gross debt, which might also be affected by e.g. sales of public assets.
} 
Table 1: Successful fiscal adjustments. Copy of table 5 in Alesina and Ardagna (2010).

\begin{tabular}{|c|c|c|c|c|c|c|c|c|}
\hline & \multicolumn{4}{|c|}{ Successful } & \multicolumn{4}{|c|}{ Unsuccessful } \\
\hline & $\begin{array}{c}{[\mathrm{T}-2-\mathrm{T}-1]} \\
\text { (a) }\end{array}$ & $\begin{array}{c}\mathrm{T} \\
\text { (b) }\end{array}$ & $\begin{array}{c}{[\mathrm{T}+1-\mathrm{T}+2]} \\
\text { (c) }\end{array}$ & (c) - (a) & $\begin{array}{c}{[\mathrm{T}-2-\mathrm{T}-1]} \\
\text { (a) }\end{array}$ & $\begin{array}{c}\mathrm{T} \\
\text { (b) }\end{array}$ & $\begin{array}{c}{[\mathrm{T}+1-\mathrm{T}+2]} \\
\text { (c) }\end{array}$ & (c) - (a) \\
\hline Debt & $\begin{array}{l}61.92 \\
(4.32)\end{array}$ & $\begin{array}{l}59.63 \\
(4.50)\end{array}$ & $\begin{array}{l}53.18 \\
(4.16)\end{array}$ & -8.74 & $\begin{array}{l}68.29 \\
(4.32)\end{array}$ & $\begin{array}{c}71.4 \\
(4.53)\end{array}$ & $\begin{array}{l}72.06 \\
(4.48)\end{array}$ & 3.77 \\
\hline Change in debt & $\begin{array}{c}-1.6 \\
(0.72)\end{array}$ & $\begin{array}{l}-1.97 \\
(1.14)\end{array}$ & $\begin{array}{l}-3.88 \\
(0.34)\end{array}$ & -2.28 & $\begin{array}{c}3.68 \\
(0.64)\end{array}$ & $\begin{array}{c}2.29 \\
(0.53)\end{array}$ & $\begin{array}{c}2.14 \\
(0.43)\end{array}$ & -1.54 \\
\hline Total deficit & $\begin{array}{c}2.5 \\
(1.00)\end{array}$ & $\begin{array}{c}0.29 \\
(1.06)\end{array}$ & $\begin{array}{c}0.66 \\
(1.09)\end{array}$ & -1.84 & $\begin{array}{c}5.6 \\
(0.71)\end{array}$ & $\begin{array}{c}3.77 \\
(0.83)\end{array}$ & $\begin{array}{c}3.69 \\
(0.85)\end{array}$ & -1.91 \\
\hline Primary deficit & $\begin{array}{c}0.8 \\
(0.68)\end{array}$ & $\begin{array}{c}-1.2 \\
(0.64)\end{array}$ & $\begin{array}{l}-0.64 \\
(0.69)\end{array}$ & -1.44 & $\begin{array}{c}2.7 \\
(0.45)\end{array}$ & $\begin{array}{c}0.71 \\
(0.51)\end{array}$ & $\begin{array}{c}0.57 \\
(0.46)\end{array}$ & -2.13 \\
\hline Primary expenditures & $\begin{array}{l}45.78 \\
(1.76)\end{array}$ & $\begin{array}{l}43.67 \\
(1.60)\end{array}$ & $\begin{array}{l}43.83 \\
(1.46)\end{array}$ & -1.95 & $\begin{array}{l}43.46 \\
(1.10)\end{array}$ & $\begin{array}{l}42.68 \\
(1.10)\end{array}$ & $\begin{array}{l}42.74 \\
(1.03)\end{array}$ & -0.72 \\
\hline Transfers & $\begin{array}{l}19.86 \\
(1.11)\end{array}$ & $\begin{array}{l}19.07 \\
(0.94)\end{array}$ & $\begin{array}{l}19.03 \\
(0.89)\end{array}$ & -0.83 & $\begin{array}{l}18.38 \\
(0.63)\end{array}$ & $\begin{array}{l}18.59 \\
(0.64)\end{array}$ & $\begin{array}{l}18.81 \\
(0.61)\end{array}$ & 0.43 \\
\hline Government wage expenditures & $\begin{array}{l}12.82 \\
(0.69)\end{array}$ & $\begin{array}{c}12.5 \\
(0.67)\end{array}$ & $\begin{array}{c}12.3 \\
(0.63)\end{array}$ & -0.52 & $\begin{array}{l}12.51 \\
(0.44)\end{array}$ & $\begin{array}{c}12.3 \\
(0.42)\end{array}$ & $\begin{array}{l}12.19 \\
(0.40)\end{array}$ & -0.32 \\
\hline Government non wage expenditures & $\begin{array}{c}8.73 \\
(0.49)\end{array}$ & $\begin{array}{c}8.62 \\
(0.47)\end{array}$ & $\begin{array}{c}8.71 \\
(0.45)\end{array}$ & -0.02 & $\begin{array}{c}7.96 \\
(0.30)\end{array}$ & $\begin{array}{c}8.01 \\
(0.31)\end{array}$ & $\begin{array}{c}8 \\
(0.30)\end{array}$ & 0.04 \\
\hline Subsidies & $\begin{array}{l}2.29 \\
(0.36)\end{array}$ & $\begin{array}{c}2.14 \\
(0.35)\end{array}$ & $\begin{array}{l}2.05 \\
(0.34)\end{array}$ & -0.24 & $\begin{array}{c}2.05 \\
(0.14)\end{array}$ & $\begin{array}{c}1.94 \\
(0.14)\end{array}$ & $\begin{array}{c}1.93 \\
(0.15)\end{array}$ & -0.12 \\
\hline Government investment & $\begin{array}{c}2.12 \\
(0.38)\end{array}$ & $\begin{array}{c}1.34 \\
(0.34)\end{array}$ & $\begin{array}{c}1.74 \\
(0.27)\end{array}$ & -0.38 & $\begin{array}{c}2.57 \\
(0.19)\end{array}$ & $\begin{array}{l}1.85 \\
(0.18)\end{array}$ & $\begin{array}{c}1.81 \\
(0.16)\end{array}$ & -0.76 \\
\hline Total revenue & $\begin{array}{l}44.98 \\
(1.61)\end{array}$ & $\begin{array}{l}44.86 \\
(1.57)\end{array}$ & $\begin{array}{l}44.47 \\
(1.67)\end{array}$ & -0.51 & $\begin{array}{l}40.76 \\
(1.04)\end{array}$ & $\begin{array}{l}41.97 \\
(1.04)\end{array}$ & $\begin{array}{l}42.17 \\
(1.03)\end{array}$ & 1.41 \\
\hline Income taxes & $\begin{array}{l}13.69 \\
(1.18)\end{array}$ & $\begin{array}{l}13.43 \\
(1.17)\end{array}$ & $\begin{array}{c}13 \\
(1.16)\end{array}$ & -0.69 & $\begin{array}{l}11.02 \\
(0.64)\end{array}$ & $\begin{array}{l}11.35 \\
(0.65)\end{array}$ & $\begin{array}{l}11.55 \\
(0.64)\end{array}$ & 0.53 \\
\hline Business taxes & $\begin{array}{c}2.77 \\
(0.26)\end{array}$ & $\begin{array}{c}3.37 \\
(0.31)\end{array}$ & $\begin{array}{c}3.59 \\
(0.35)\end{array}$ & 0.82 & $\begin{array}{c}2.69 \\
(0.22)\end{array}$ & $\begin{array}{c}3.08 \\
(0.28)\end{array}$ & $\begin{array}{c}3.1 \\
(0.31)\end{array}$ & 0.41 \\
\hline Indirect taxes & $\begin{array}{l}13.77 \\
(0.68)\end{array}$ & $\begin{array}{c}13.6 \\
(0.61)\end{array}$ & $\begin{array}{l}13.46 \\
(0.62)\end{array}$ & -0.31 & $\begin{array}{l}12.32 \\
(0.33)\end{array}$ & $\begin{array}{l}12.51 \\
(0.32)\end{array}$ & $\begin{array}{l}12.63 \\
(0.33)\end{array}$ & 0.31 \\
\hline Social security contributions & $\begin{array}{l}10.82 \\
(1.26)\end{array}$ & $\begin{array}{l}10.73 \\
(1.15)\end{array}$ & $\begin{array}{l}10.73 \\
(1.20)\end{array}$ & -0.09 & $\begin{array}{l}12.04 \\
(0.62)\end{array}$ & $\begin{array}{l}12.25 \\
(0.62)\end{array}$ & $\begin{array}{l}12.15 \\
(0.64)\end{array}$ & 0.11 \\
\hline
\end{tabular}

The table reports the yearly averages of the variables for three time periods: the two years prior to the adjustment $(T-2$ and $T-1)$, the adjustment year $(T)$, and the two years after the adjustment $(T+1$ and $T+2)$, as well as the difference between the periods after and prior to the adjustment (column (c) - (a)). All variables are measured as ratios to nominal GDP. Total deficit, primary deficit, primary expenditures, transfers, total revenue and all revenue items are cyclically adjusted. Standard deviations of the means in parenthesis. 
Regarding the other important factor in equation (1), that growth in GDP reduces the debt-to-GDP ratio, Alesina and Ardagna (2010) argue that the composition of the adjustment affects growth, but they do not discuss the difference in initial conditions. Table 2, which is a copy of table 6 in Alesina and Ardagna (2010), shows that the economy is in a much better state prior to successful adjustments than prior to unsuccessful. ${ }^{10}$ GDP growth in the two years prior to the fiscal adjustment (i.e. years $T-2$ and $T-1)$ is on average almost one percentage point higher $(2.99$ as opposed to 2.07), total investment growth almost two percentage points higher (2.95 compared to 1.02), and the trade balance almost three percentage points higher (2.72 compared to -0.19). As GDP growth generally is rather persistent, the one percentage point higher GDP growth during the successful adjustments than during the unsuccessful (for both year $T$ and the average of years $T+1$ and $T+2$ ), contributing to a larger reduction in the debt-to-GDP ratio, is likely to, at least to some extent, reflect better initial conditions, including higher initial GDP growth.

Table 2: Successful fiscal adjustments. Growth components. Copy of table 6 in Alesina and Ardagna (2010).

\begin{tabular}{|c|c|c|c|c|c|c|c|c|}
\hline & \multicolumn{4}{|c|}{ Successful } & \multicolumn{4}{|c|}{ Unsuccessful } \\
\hline & $\begin{array}{c}{[\mathrm{T}-2-\mathrm{T}-1]} \\
\text { (a) }\end{array}$ & $\begin{array}{c}\mathrm{T} \\
\text { (b) }\end{array}$ & $\begin{array}{c}{[\mathrm{T}+1-\mathrm{T}+2]} \\
\text { (c) }\end{array}$ & (c) - (a) & $\begin{array}{c}{[\mathrm{T}-2-\mathrm{T}-1]} \\
\text { (a) }\end{array}$ & $\begin{array}{c}\mathrm{T} \\
\text { (b) }\end{array}$ & $\begin{array}{c}{[\mathrm{T}+1-\mathrm{T}+2]} \\
\text { (c) }\end{array}$ & (c) - (a) \\
\hline G7 GDP Growth & $\begin{array}{c}0.4 \\
(0.53)\end{array}$ & $\begin{array}{c}0.8 \\
(0.46)\end{array}$ & $\begin{array}{c}0.85 \\
(0.37)\end{array}$ & 0.45 & $\begin{array}{l}-0.18 \\
(0.23)\end{array}$ & $\begin{array}{l}-0.22 \\
(0.22)\end{array}$ & $\begin{array}{l}-0.12 \\
(0.18)\end{array}$ & 0.06 \\
\hline GDP Growth & $\begin{array}{c}2.99 \\
(0.58)\end{array}$ & $\begin{array}{l}3.61 \\
(0.5)\end{array}$ & $\begin{array}{c}3.45 \\
(0.28)\end{array}$ & 0.46 & $\begin{array}{c}2.07 \\
(0.25)\end{array}$ & $\begin{array}{l}2.56 \\
(0.2)\end{array}$ & $\begin{array}{c}2.52 \\
(0.21)\end{array}$ & 0.45 \\
\hline Private Consumption Growth & $\begin{array}{l}2.75 \\
(0.6)\end{array}$ & $\begin{array}{c}3.74 \\
(0.67)\end{array}$ & $\begin{array}{l}3.02 \\
(0.3)\end{array}$ & 0.27 & $\begin{array}{c}2.01 \\
(0.26)\end{array}$ & $\begin{array}{c}2.28 \\
(0.23)\end{array}$ & $\begin{array}{l}2.42 \\
(0.2)\end{array}$ & 0.41 \\
\hline Total Investment Growth & $\begin{array}{c}2.95 \\
(1.37)\end{array}$ & $\begin{array}{c}4.11 \\
(1.54)\end{array}$ & $\begin{array}{c}4.78 \\
(1.24)\end{array}$ & 1.83 & $\begin{array}{c}1.02 \\
(0.69)\end{array}$ & $\begin{array}{c}2.55 \\
(0.56)\end{array}$ & $\begin{array}{c}3.52 \\
(0.73)\end{array}$ & 2.5 \\
\hline Private Investment Growth & $\begin{array}{c}3.45 \\
(1.46)\end{array}$ & $\begin{array}{c}5.6 \\
(1.85)\end{array}$ & $\begin{array}{c}5.07 \\
(1.43)\end{array}$ & 1.62 & $\begin{array}{c}1.18 \\
(0.81)\end{array}$ & $\begin{array}{c}3.43 \\
(0.73)\end{array}$ & $\begin{array}{l}4.23 \\
(0.9)\end{array}$ & 3.05 \\
\hline Business Investment Growth & $\begin{array}{c}3.2 \\
(1.79)\end{array}$ & $\begin{array}{c}5.46 \\
(2.06)\end{array}$ & $\begin{array}{c}6.06 \\
(1.42)\end{array}$ & 2.86 & $\begin{array}{c}3.23 \\
(1.07)\end{array}$ & $\begin{array}{c}5.17 \\
(0.97)\end{array}$ & $\begin{array}{c}5.84 \\
(1.08)\end{array}$ & 2.61 \\
\hline Trade Balance & $\begin{array}{l}2.72 \\
(1.1)\end{array}$ & $\begin{array}{c}3.99 \\
(1.03)\end{array}$ & $\begin{array}{c}4.31 \\
(1.51)\end{array}$ & 1.59 & $\begin{array}{l}-0.19 \\
(0.71)\end{array}$ & $\begin{array}{c}0.48 \\
(0.77)\end{array}$ & $\begin{array}{c}1.15 \\
(0.84)\end{array}$ & 1.34 \\
\hline
\end{tabular}

The table reports the yearly averages of the variables for three time periods: the two years prior to the adjustment $(T-2$ and $T-1)$, the adjustment year $(T)$, and the two years after the adjustment $(T+1$ and $T+2)$, as well as the difference between the periods after and prior to the adjustment (column (c) - (a)). Standard deviations of the means in parenthesis.

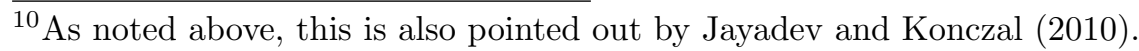


Then consider our claim that Alesina and Ardagna (2010) use an imprecise measure of changes in fiscal policy. As noted above, Alesina and Ardagna (2010) use cyclically adjusted values of the ratio of expenditure and taxes to GDP, where the adjustment is based on the change in unemployment. ${ }^{11}$ However, as we illustrate in table 5 below, this adjustment is of limited use as the fiscal variables are not very responsive to changes in unemployment. ${ }^{12}$ Furthermore, it is problematic to use the change in the ratio of expenditures to GDP as a measure of changes in expenditure, as this ratio will be affected by changes in both the numerator and the denominator. This involves a risk of reverse causality: if GDP falls for whatever reason, this will imply an increase in the public expenditure as a ratio to GDP, even if expenditure has not changed. A fall in GDP will also push up the ratio of debt to GDP. ${ }^{13}$ Correspondingly, if GDP increases, for whatever reason, this will involve a tendency that both the expenditure to GDP ratio and the debt to GDP ratio fall. Thus, there is a risk that one misleadingly concludes that changes in debt follow changes in expenditure, even if in these cases it is the change in GDP that drives both variables.

There is no similar effect for taxes. When GDP growth is high, tax bases and thus also tax revenues are also likely to increase, so there is no inherent tendency of a fall in the ratio of tax revenues to GDP.

This reverse causality argument also applies to the findings on the effect on growth. Alesina and Ardagna (2010) find that adjustments based on spending reductions are more likely to be expansionary than adjustments based on tax increases. We argue that this finding is the result of reverse causality: in episodes where GPD for whatever reason is high, there will be a tendency that the expenditure to GDP ratio falls. In contrast, there will be a tendency that the expenditure to GDP

\footnotetext{
${ }^{11}$ For government expenditure, only transfers are cyclically adjusted.

${ }^{12}$ Incidentally, Alesina and Ardagna (2010) note that "even not correcting at all would give similar results.

${ }^{13}$ This point is acknowledged in Alesina and Perotti (1995), who also use other measures of the cyclically adjusted budget balance. However, these measures also have insufficient adjustment for the cyclical change in GDP.
} 
ratio increases in episodes where GDP for some reason falls. We evaluate the importance of this argument in the next section.

As noted, Alesina and Perotti (1995) undertake a similar analysis as Alesina and Ardagna (2010), even if the sample and exact definitions do not match. Alesina and Perotti (1995) also find that successful adjustments are associated with cuts in government expenditure, while unsuccessful adjustments are associated with tax rises. Unfortunately, they do not provide information about the budget deficit before or during the adjustment, as they only focus on the cyclically adjusted change in the budget deficit in the year of fiscal adjustment (i.e. year $T$ ). However, they report the country years of the fiscal adjustments, as well as which of them are successful, so it is possible to calculate the mean value of the total deficit in the two periodes prior to the adjustment, in the adjustment year, and in the two following years. ${ }^{14}$ We find that while there is little difference in the budget deficit prior to the adjustment (3.9 percent of GDP in successful episodes and 3.6 percent in unsuccessful), this changes sharply with the adjustment. In the successful episodes, the budget deficit is reduced to 0.9 percent in the adjustment year, and a small surplus of 0.2 percent on average in the following two years. In contrast, the deficit remains in the unsuccessful episodes: 2.0 percent in the adjustment year and 3.0 percent on average in the following two years. Thus, there is no surprise that these adjustments fail, as they fail to remove the budget deficit. Again, the message is that to reduce debt, one should tighten sufficiently to ensure a positive budget balance. The results can thus not be used to argue that achieving a positive budget balance via large tax increases will fail to reduce debt. $^{15}$

\footnotetext{
${ }^{14}$ We use data from the OECD Economic Outlook December 1996 database, to make the replication as similar as possible to their data (EO databases from 1995 are not available in the OECD library).

${ }^{15}$ Alesina and Perotti (1995) argue that one reason for spending-based adjustments being successful is that they induce higher economic growth. However, the effect on growth must be very large to explain a difference in budget deficit ratios of more than 3 percentage points one and two years after the adjustment.
} 


\subsection{The reverse causality argument - A replication study}

The aim of this section is to evaluate our claim that the results of Alesina and Ardagna (2010) are affected by reverse causality. To this end, we first replicate their analysis, using the same data source, countries, years and episode definitions. Furthermore, we cyclically adjust the variables in the same way, using the BFI method as explained above. We then redo the analysis with a modified approach, which is constructed to avoid the risk of reverse causality. This is ensured by undertaking the cyclical adjustment directly on the expenditure and revenue components and not on these variables as ratios to GDP. The resulting fiscal variable is then divided by a predetermined measure of trend GDP, to make the results comparable to those of Alesina and Ardagna (2010).

First, consider the cyclical adjustment using the BFI on transfers and revenue components. Because these variables are non-stationary when they are not measured as ratios to GDP, we run the regressions on differences:

$$
\Delta T_{t}=\alpha_{0}+\alpha_{1} \text { Trend }_{t}+\alpha_{3} \Delta U_{t}+\epsilon_{t}
$$

where Trend $_{t}$ is a time trend and $\Delta U_{t}$ is the change in the rate of unemployment. The cyclically adjusted variables for the year of adjustment and the two subsequent years are then given by:

$$
T_{t+k}^{c a}=T_{t+k}-\hat{\alpha}_{3}\left[\sum_{i=0}^{k} \Delta U_{t+i}\right], \quad k=0,1,2
$$

The predetermined trend GDP, $Y_{t}^{*}$, is calculated on the basis of nominal GDP prior to the adjustment (i.e. in period $t-1$ ), multiplied by our measure of trend GDP growth.

$$
Y_{t+k}^{*}=Y_{t-1} \prod_{i=0}^{k}\left(1+\Delta y_{t+i}^{\text {trend }}\right), k=0,1,2
$$

where $\Delta y_{t}^{\text {trend }}$ is nominal trend GDP growth, defined as ten-year lagged moving average of real GDP transformed to current prices by a three-year lagged moving 
average of GDP deflator growth. ${ }^{16}$ The cyclically adjusted ratios to GDP are now obtained by dividing the cyclically adjusted tax levels $T_{t}^{c a}$ and the corresponding levels for transfers and the primary budget deficit by our measure of predetermined GDP, $Y_{t}^{*}$, for the initial year of the fiscal adjustment episode and the two years after (i.e.we calculate $T_{t+k}^{c a} / Y_{t+k}^{*}$ for $k=0,1,2$ ).

Table 3 and 4 compare the results copied from Alesina and Ardagna (2010) (column $A A$ ), our replica of the Alesina and Ardagna (2010) approach (column Replica), and our alternative measure with cyclical adjustment of the budgetary components, divided by our predetermined GDP (column Alternative). The tables are compressed into displaying the difference in the average of the two years after the adjustment and the mean average of the two years prior to the adjustment. Full versions of the tables are available in the appendix, see tables 12-13. The replica is based on the same method and data source as Alesina and Ardagna (2010), yet the selection of episodes and the results differ somewhat. ${ }^{17}$ Note that for the column with the alternative measure, we use the years identified as expansionary and successful episodes in the replica, to ensure that any difference between the columns reflects the difference in the fiscal measure.

Both tables support our hypothesis that what seems like differences in fiscal policy behavior, in reality is driven by differences in growth. Consider first the effect on whether the adjustment is successful in reducing the debt to GDP ratio, in table 3, where the key results are illustrated in figure 1. The replica reproduces the essential findings of Alesina and Ardagna (2010): Successful adjustments are based on large reductions in primary expenditure and small changes in total tax revenues, while unsuccessful adjustments are based on small reductions in primary expenditure and large increases in total revenues. However, when we use our alternative measure, i.e. divide by predetermined trend GDP to avoid reverse causality, the picture

\footnotetext{
${ }^{16}$ We use a backward-looking measure of trend GDP to avoid that the change in fiscal policy might affect trend GDP via the effect on GDP in subsequent years. The exact definition of trend GDP growth is not crucial for our results.

${ }^{17}$ As we follow the method described in Alesina and Ardagna (2010), we should in principle obtain exactly the same result. Possibly, there might be revisions in the OECD Economic Outlook database (Nr.84) between the extraction of the two data sets, and since we use an econometrical exercise to obtain the discretionary budget variable,the analysis is sensitive to small data changes. 85 of the 94 years of fiscal adjustment that we find match with the findings in Alesina and Ardagna (2010). For more details on the replication analysis, see appendix A.
} 
is very different. Now, the average reduction in primary expenditure is in fact slightly larger in the unsuccessful adjustments. The increase in total revenue is also somewhat larger in the unsuccessful adjustments, but the overall conclusion is clear: these results provide no reason to conclude that spending cuts is a more efficient tool to reduce debt than tax increases.

Figure 1: Budget changes during successful and unsuccessful adjustments Changes in primary expenditure
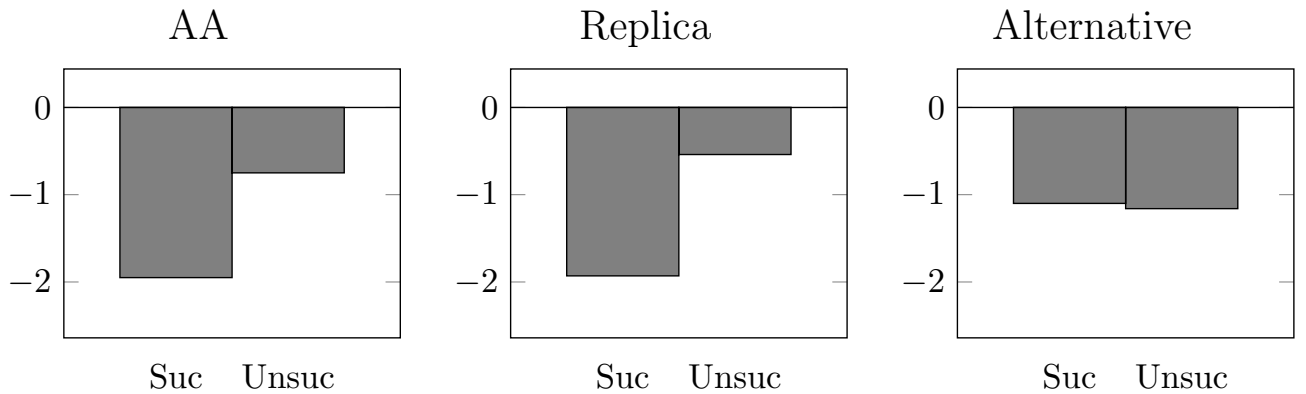

Changes in total revenue
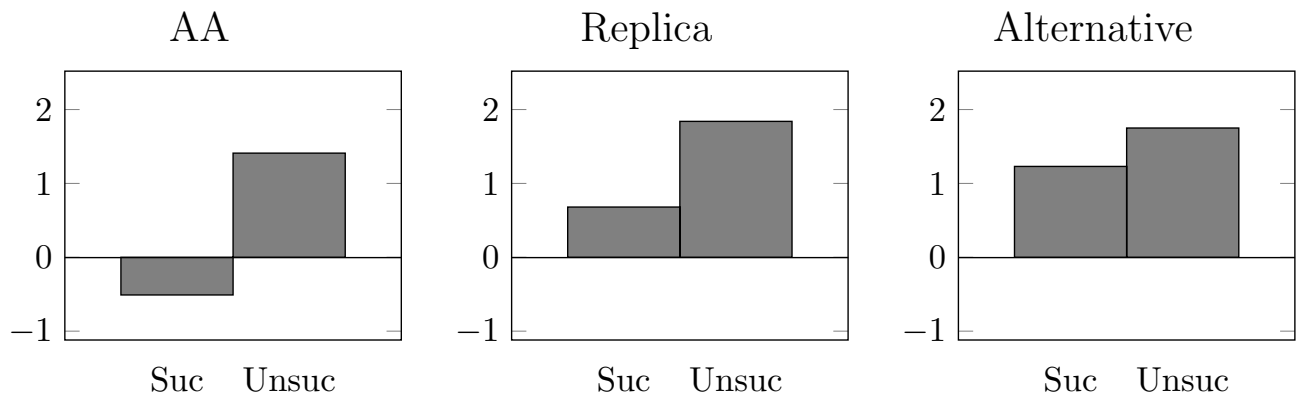

Changes in primary expenditure and total revenues from table 3 
Table 3: Change in key variables during successful and unsuccessful adjustment episodes.

\begin{tabular}{lcccccc}
\hline \hline & \multicolumn{3}{c}{ Successful } & \multicolumn{3}{c}{ Unsuccessful } \\
& $(\mathrm{AA})$ & Replica & Alternative & (AA) & Replica & Alternative \\
\hline & & & & & & \\
Debt & -8.74 & -11.12 & -10.20 & 3.77 & 4.14 & 3.78 \\
Change in Debt & -2.28 & -3.60 & -3.54 & -1.54 & -2.36 & -1.89 \\
Total deficit & -1.84 & -3.40 & -3.16 & -1.91 & -2.22 & -2.80 \\
Primary deficit & -1.44 & -2.60 & -2.33 & -2.13 & -2.38 & -2.91 \\
Primary Expenditure & -1.95 & -1.93 & -1.10 & -0.72 & -0.54 & -1.16 \\
Transfers & -0.83 & -0.88 & -0.62 & 0.43 & 0.21 & -0.21 \\
Government consumption & -0.54 & -0.84 & -0.38 & -0.36 & -0.24 & -0.39 \\
Subsidies & -0.24 & -0.27 & -0.24 & -0.12 & -0.18 & -0.20 \\
Government investment & -0.38 & -0.02 & 0.04 & -0.76 & -0.33 & -0.36 \\
Total revenue & -0.51 & 0.68 & 1.23 & 1.41 & 1.84 & 1.75 \\
Business Taxes & 0.82 & 0.93 & 1.00 & 0.53 & 0.40 & 0.51 \\
Income Taxes & -0.69 & -0.05 & 0.07 & 0.41 & 0.79 & 0.70 \\
Indirect Taxes & -0.31 & 0.04 & 0.29 & 0.31 & 0.32 & 0.28 \\
Social Security Contr. & -0.09 & -0.24 & -0.14 & 0.11 & 0.33 & 0.26 \\
\hline \hline
\end{tabular}

A fiscal adjustment episode is defined as successful if the cumulative change in the debt to GDP ratio from the year of adjustment and two years forward is smaller than the 25th percentile of the same variable's empirical density in all episodes of fiscal adjustments.

The table shows the difference between the average of the two years after the adjustment and the average of the two years prior to the adjustment, corresponding to column (c)-(a) in Table 1. All variables in AA and the replica are measured as ratios to GDP, whereas in the alternative, the variables are measured as ratio to GDP for the two years prior to the adjustment, and as ratio to trend GDP for the adjustment year and the two years after the adjustment. The deficit variables, primary expenditure, transfers, total revenue and all revenue components are cyclically adjusted. For full versions of the tables, see table 11 and table 13 in appendix A.

Next, consider the effect on economic growth, displayed in figure 2 and table 4 . Here, too, the broad picture is the same in AA and our replica: expansionary adjustments are characterised by considerably larger spending cuts than contractionary adjustments, while the opposite is true for tax hikes, which are larger in the contractionary adjustments. Again, the results are changed when we consider our alternative measure based on trend-GDP. Compared to Alesina and Ardagna (2010) and the replica, the expenditure cut is smaller in expansionary adjustments and larger in contractionary adjustments. Even if the reduction in expenditure is somewhat larger in expansionary adjustments than in contractionary, the same is true for the increase in total revenues, as total revenues increase slightly more in expansionary adjustments than in contractionary. Note also that the change in government consumption is the same in expansionary and contractionary episodes, so the difference is due to transfers falling more in expansionary episodes. Clearly, 
here there might also be an element of reverse causality, as high economic growth usually leads to a reduction in the number of recipients of benefits and transfers. The overall conclusion is that these results provide no clear reason to argue that spending cuts are more expansionary than tax rises.

Figure 2: Budget changes during expansionary and contractionary adjustments

$\mathrm{AA}$

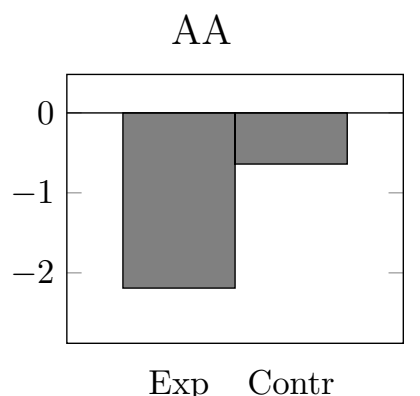

Exp Contr

Changes in primary expenditure

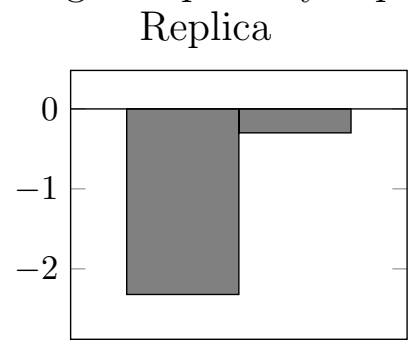

Exp Contr
Alternative

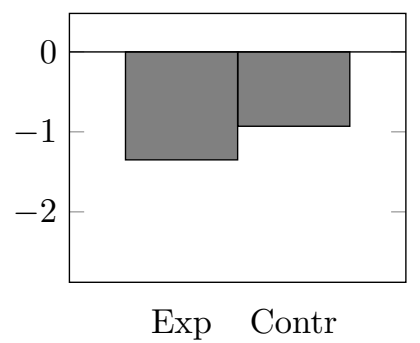

Changes in total revenue

AA

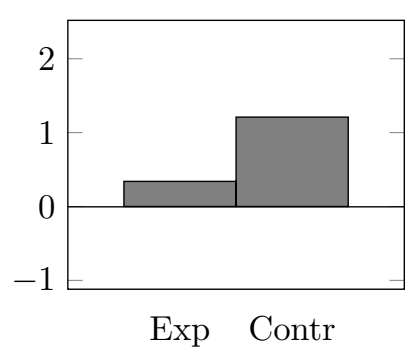

Replica

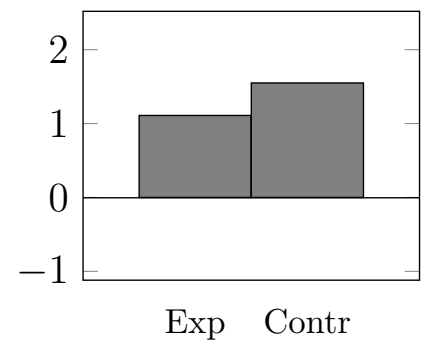

Alternative

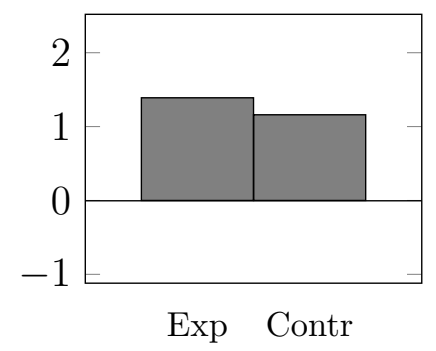

Changes in primary expenditure and total revenues from table 4 
Table 4: Change in key variables during expansionary and contractionary adjustment episodes

\begin{tabular}{lcccccc}
\hline \hline & \multicolumn{3}{c}{ Expansionary } & \multicolumn{3}{c}{ Contractionary } \\
& $(\mathrm{AA})$ & Replica & Alternative & (AA) & Replica & Alternative \\
\hline & & & & & & \\
Debt & -5.76 & -5.22 & -3.87 & 0.37 & 1.89 & 1.45 \\
Change in Debt & -0.84 & -3.37 & -3.11 & -2.00 & -2.47 & -2.06 \\
Total deficit & -3.05 & -4.34 & -3.65 & -1.53 & -1.46 & -1.76 \\
Primary deficit & -2.54 & -3.44 & -2.74 & -1.85 & -1.84 & -2.09 \\
Primary Expenditure & -2.19 & -2.32 & -1.35 & -0.64 & -0.30 & -0.93 \\
Transfers & -0.58 & -0.98 & -0.67 & 0.47 & 0.48 & 0.14 \\
Government consumption & -0.53 & -0.87 & -0.33 & -0.32 & -0.24 & -0.46 \\
Subsidies & -0.32 & -0.35 & -0.31 & -0.09 & -0.15 & -0.17 \\
Government investment & -0.77 & -0.12 & -0.03 & -0.70 & -0.43 & -0.47 \\
Total revenue & 0.34 & 1.11 & 1.39 & 1.21 & 1.55 & 1.16 \\
Business Taxes & 0.66 & 0.60 & 0.67 & 0.35 & 0.41 & 0.45 \\
Income Taxes & -0.27 & 0.47 & 0.43 & 0.48 & 0.81 & 0.59 \\
Indirect Taxes & 0.01 & 0.40 & 0.53 & 0.21 & 0.30 & 0.17 \\
Social Security Contr. & -0.07 & -0.36 & -0.24 & -0.06 & 0.28 & 0.22 \\
\hline \hline
\end{tabular}

A fiscal adjustment episode is defined as expansionary when average GDP growth, in difference from the G7 average, from the year of adjustment and two years forward is larger than the 75th percentile of the same variable's empirical density in all episodes of adjustment.

The table shows the difference between the average of the two years after the adjustment and the average of the two years prior to the adjustment. All variables in AA and the replica are measured as ratios to GDP, whereas in the alternative, the variables are measured as ratio to GDP for the two years prior to the adjustment, and as ratio to trend GDP for the adjustment year and the two years after the adjustment. The deficit variables, primary expenditure, transfers, total revenue and all revenue components are cyclically adjusted. For full versions of the tables, see table 12 and table 14 in appendix A.

\section{A new fiscal measure}

A weakness of the analysis above is that it is based on a rather imprecise measure of changes in fiscal policy, as unemployment is only weakly correlated with tax revenues, cf. Table 5. An imprecise measure will affect both the selection of adjustment years and the measure of the policy in those years. Thus, in this section we will consider the same issue as above, but now using a more precise measure of changes in fiscal policy, first suggested in Holden and Midthjell (2013). The main idea behind this novel measure of fiscal policy changes (the HoldenMidthjell (HM) fiscal indicator) is to exploit that changes in tax revenues are closely linked 
to changes in their respective tax bases, cf. Table $5 .^{18}$

Table 5: Correlation with tax revenues and expenditure components

\begin{tabular}{lcc}
\hline \hline \multicolumn{1}{c}{ Variable } & Tax base & Unemployment \\
\hline Income tax & 0.71 & -0.15 \\
Business Tax & 0.26 & -0.18 \\
Indirect taxes & 0.74 & -0.20 \\
Soc.sec contributions & 0.66 & 0.01 \\
Gov. purchases & - & 0.06 \\
Subsidies & - & 0.07 \\
Social Security (excl. UB) & - & 0.18 \\
Unemployment Benefits & - & 0.61 \\
\hline \hline
\end{tabular}

Correlation of tax bases and unemployment with tax revenue categories/ expenditure components, measured for all countries and years in the sample. All variables in growth terms.

\subsection{A new measure of discretionary fiscal policy changes: The HM fiscal indicator}

In this subsection we present the construction of the HM fiscal indicator that we use in the subsequent analysis. ${ }^{19}$ For tax revenues, the HM indicator is based on the idea that constant policy can be defined as tax revenues being a constant share of the associated tax base. With this definition, an induced change in tax revenues (i.e. changes in tax revenues under constant fiscal policy) of category $i$ is given by:

$$
\Delta T_{i, t}^{i n d}=T_{i, t-1}\left(\frac{Z_{i . t}}{Z_{i, t-1}}-1\right)
$$

where $T_{i}$ is actual tax revenue and $Z_{i}$ is the related tax base. Revenues are divided into the following four categories with respective tax bases in parenthesis: Direct taxes on households (pre-tax household income), direct taxes on business (profits), social security contributions (the wage bill), and indirect taxes (private

\footnotetext{
${ }^{18}$ Business taxes is the exception, but this component is much smaller than the others (about 5 percent of total revenue on average).

${ }^{19}$ For further discussion and motivation of the indicator, see Holden and Midthjell (2013).
} 
consumption). Changes in other taxes are treated as induced. ${ }^{20}$ The discretionary change in tax category $i$ is then calculated as the residual:

$$
\Delta T_{i, t}^{d i s c r}=\Delta T_{i, t}-\Delta T_{i, t}^{i n d}
$$

The total discretionary tax change is defined as the sum of the discretionary change in all four tax categories:

$$
\Delta T_{t}^{d i s c r}=\sum_{i=1}^{4} \Delta T_{i, t}^{d i s c r}
$$

For government expenditure, we distinguish between purchases (i.e. government consumption and investment) and transfers. For purchases, we will argue that a reasonable definition of constant policy is that purchases are constant in real terms. ${ }^{21}$ Thus, the induced change in government purchases is the change associated with changing prices:

$$
\Delta G P_{i, t}^{i n d}=G P_{i, t-1} \Delta p_{i, t}^{G P d e f}
$$

where $G P_{i, t}$ is government purchases in period $t, \Delta p_{i, t}^{G P d e f}$ is the growth rate in the government purchases price deflator, and where subscript $i$ indicates purchase component, i.e. consumption or investment.

The discretionary change for expenditure category $i$ is defined as the actual change less the induced change under constant policy:

$$
\begin{aligned}
\Delta G P_{i, t}^{\text {discr }} & =\Delta G P_{i, t}-\Delta G P_{i, t}^{\text {ind }} \\
\Rightarrow \Delta G P_{t}^{\text {discr }} & =\sum_{i=1}^{2} \Delta G P_{i, t}^{\text {discr }}
\end{aligned}
$$

For all transfers except unemployment benefits, we define unchanged fiscal policy in

\footnotetext{
${ }^{20}$ The cyclical adjustment by the OECD distinguishes the same tax categories. However, the OECD adjustment method links the adjustment of the tax categories to the aggregate output gap, and not to the associated tax base. This leads to a less precise measure if tax bases evolve differently than the GDP does.

${ }^{21}$ Ideally, one might want to associate constant policy with no new decisions. However, at this level of aggregation this definition is impossible to implement.
} 
the same way as for government purchases, as being constant in real terms. As most transfers are to private households, it seems reasonable to use the consumption price index as deflator. For unemployment benefits, unchanged policy is defined as unemployment benefits per unemployed person being constant in real terms. Thus, the induced change in unemployment benefits reflects changes in consumer prices as well as changes in the number of unemployed persons:

$$
\Delta U B_{t}^{i n d}=U B_{t-1}\left(\frac{U L_{t}}{U L_{t-1}} \frac{C P I_{t}}{C P I_{t-1}}-1\right)
$$

where $U B$ is expenditure on unemployment benefits, $U L$ is the number of unemployed workers, $C P I$ is the consumer price index, and $\Delta U B_{t}^{i n d}$ is the induced change in unemployment benefits in period $t$. Total induced change in transfers then becomes:

$$
\Delta \operatorname{Trans}_{t}^{\text {ind }}=(S o c-U B)_{t-1} \Delta c p i_{t}+\Delta U B_{t}^{\text {ind }}+S u b_{t-1} \Delta c p i_{t}
$$

where $S o c$ is social security contributions, $S u b$ is subsidies, and $\Delta c p i_{t}$ is CPI growth in period $t .^{22}$ The discretionary change in transfers then becomes:

$$
\Delta \operatorname{Trans}_{t}^{\text {discr }}=\Delta \operatorname{Trans}_{t}-\Delta \operatorname{Trans}_{t}^{\text {ind }}
$$

and the total discretionary change in government expenditure is:

$$
\Delta G_{t}^{\text {discr }}=\Delta G P_{t}^{\text {discr }}+\Delta \operatorname{Trans}_{t}^{\text {discr }}
$$

We then divide the discretionary changes on our measure of predetermined GDP

\footnotetext{
${ }^{22}$ This definition of induced changes does not capture any increase in the number of other types of benefit recipients during a downturn. An alternative would be to estimate the relationship between transfer expenditure and the unemployment rate, and define constant policy according to this estimated relationship. However, this might lead to large variation across countries, which would make the indicator less transparent when used for a large number of countries.
} 
for year $\mathrm{t}+\mathrm{s}$, i.e.

$$
\begin{aligned}
\Delta t_{t+k}^{\text {discr }} & =\frac{\Delta T_{t+k}^{\text {discr }}}{Y_{t+k}^{*}} \\
\Delta g p_{t+k}^{\text {discr }} & =\frac{\Delta G P_{t+k}^{\text {discr }}}{Y_{t+k}^{*}} \\
\Delta \text { trans }_{t+k}^{\text {discr }} & =\frac{\Delta \operatorname{Trans}_{t+k}^{\text {discr }}}{Y_{t+k}^{*}}
\end{aligned}
$$

To obtain a suitable indicator for the discretionary change in the budget balance, we must also adjust for the fact that over time, growth in GDP will lead to growth in the tax bases which give scope for an increase in government expenditure in real terms. Thus, with the definitions above there will be a tendency that the budget balance improves over time at constant policy. It seems more reasonable with a definition of constant policy which entails that the budget balance is constant over time. ${ }^{23}$ To ensure this we subtract an additional long run component, reflecting the effect of government purchases and transfers increasing in real terms, so that they are constant as a ratio to GDP (see appendix B for details on this measure). In the following, we now define the discretionary change in the budget balance as the discretionary change in taxes minus the discretionary change in government expenditure, and minus the long run components for changes in government purchases and transfers.

$$
\Delta B B_{t}^{\text {discr }}=\Delta T_{t}^{\text {discr }}-\Delta G_{t}^{\text {discr }}-\Delta G P_{t}^{\text {longrun }}-\Delta \text { Trans }_{t}^{\text {longrun }}
$$

\footnotetext{
${ }^{23}$ In particular, this seems reasonable when the aim is to provide a benchmark for identification of years of fiscal adjustments, as is the case here.
} 


\subsection{Empirical analysis}

We consider a panel of 24 OECD countries from 1970 to $2011 .^{24}$ Our main data source is OECD Economic Outlook Nr. 91. ${ }^{25}$ We follow Alesina and Perotti (1995), Alesina and Ardagna (2010), IMF (2010) and Perotti (2012) and concentrate on fairly large adjustments.

\section{Year of fiscal adjustment}

We define a year of fiscal adjustment as a year where the discretionary change in the primary budget balance, measured as ratio to predetermined GDP, $Y_{t}^{*}$, (as defined in equation 4 ), improves with at least 1.5 percentage points:

$$
\Delta b b_{t}^{\text {discr }}=\frac{\Delta B B_{t}^{\text {discr }}}{Y_{t}^{*}}>1.5
$$

By dividing by predetermined GDP, we ensure that changes in our fiscal variables only reflect changes in fiscal policy, and are not directly affected by the change in GDP. We follow Alesina and Ardagna (2010) in counting multiyears of adjustment as one adjustment episode.

\section{Successful Fiscal Adjustments}

A fiscal adjustment is defined as successful if the cumulative change of the debt to GDP ratio, $\frac{D}{Y}$, satisifes:

$\frac{D}{Y}_{t+2}-\frac{D}{Y} t-1<35$ th percentile of the same variable empirical density for all episodes of fiscal adjustments.

\footnotetext{
${ }^{24}$ For the countries included in the sample, we have coverage for all years for Austria, Belgium, Canada, Denmark, Finland, France, Italy, Japan, Korea, Netherlands, Norway, Sweden, United Kingdom and USA. For Australia, Spain, Portugal, Ireland, Germany and Switzerland, reliable data are only available from 1990, and for the Czech Republic, Hungary, Poland and the Slovak Republic, only from 1995. Because of limited data access, both due to non-existing budget data, and to our detailed choice of fiscal indicator, the remaining ten OECD countries are not included in the sample: Chile, Estonia, Greece, Iceland, Israel, Luxembourg, Mexico, New Zealand, Slovenia and Turkey. Compared to Alesina and Ardagna (2010), we add five countries (Czech Republic, Hungary, Korea, Poland and the Slovak Republic) and omit two countries due to lack of reliable data (Greece and New Zealand) in the empirical analysis using the HM fiscal indicator.

${ }^{25} \mathrm{~A}$ description of all data sources for all variables are available from the authors upon request.
} 
In our data sample, the 35 th percentile is -0.8 percentage points. ${ }^{26}$

\section{Expansionary Fiscal Adjustments}

An adjustment is defined as expansionary if the average GDP growth in the year of adjustment and in the two consecutive years, measured in difference from weighted G7 GDP growth, is larger than the 50th percentile of all episodes of fiscal adjustment:

$\frac{\sum_{i=0}^{2}\left(y_{t+i}-y_{t+i}^{G 7}\right)}{3}>50$ th percentile of the same variable's empirical density for all episodes of fiscal adjustments.

This definition divides the sample in two equal parts where the episodes with the highest growth differences (above 0.39 percentage points), are considered expansionary. ${ }^{27}$

As shown in table 15 in appendix B, we detect 86 years of fiscal adjustments over the sample period. All countries are represented with at least one adjustment. 23 years are consecutive adjustments so we count only 63 fiscal adjustment episodes: 46 episodes lasted one year, 12 lasted two years, 4 lasted three years and 1 (Denmark from 1983) lasted four years. 34 episodes coincide with the ones found by Alesina and Ardagna (2010). Furthermore, we detect 28 expansionary adjustment episodes and 19 successful adjustment episodes. ${ }^{28}$

\footnotetext{
${ }^{26}$ Alesina and Ardagna (2010) use a cut-off at the lowest 25th percentile for successful adjustments, corresponding to a debt reduction of -4.5 percentage points, while we choose a higher percentile to get a more equal distribution of observations between the two categories.

${ }^{27}$ Again, we depart from Alesina and Ardagna (2010) in the cut-off for expansionary adjustments (they use the 75th percentile of the distribution as the threshold) in order to get a more equal distribution of episodes.

${ }^{28}$ Table 16 in appendix B presents the expansionary and successful episodes.
} 


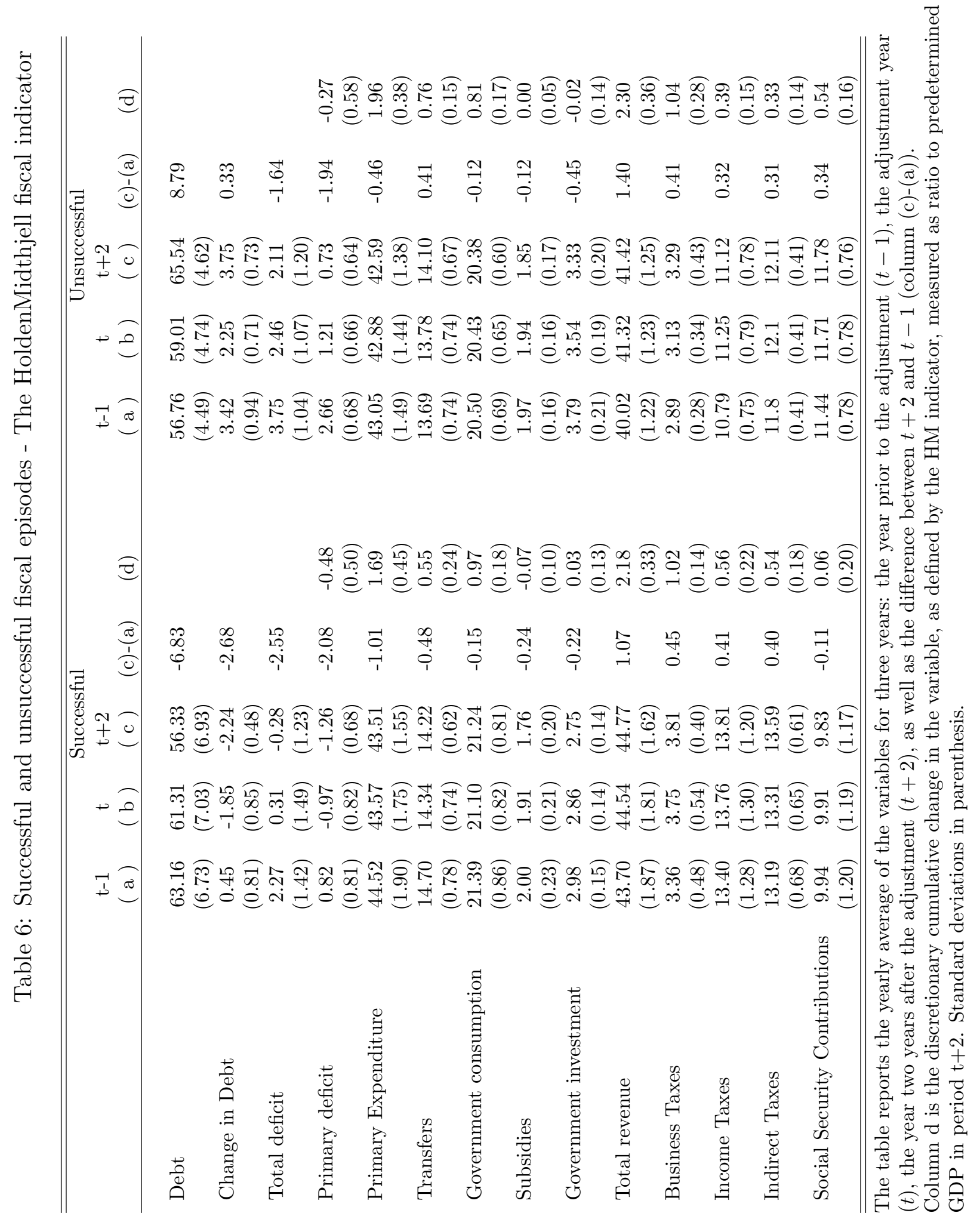




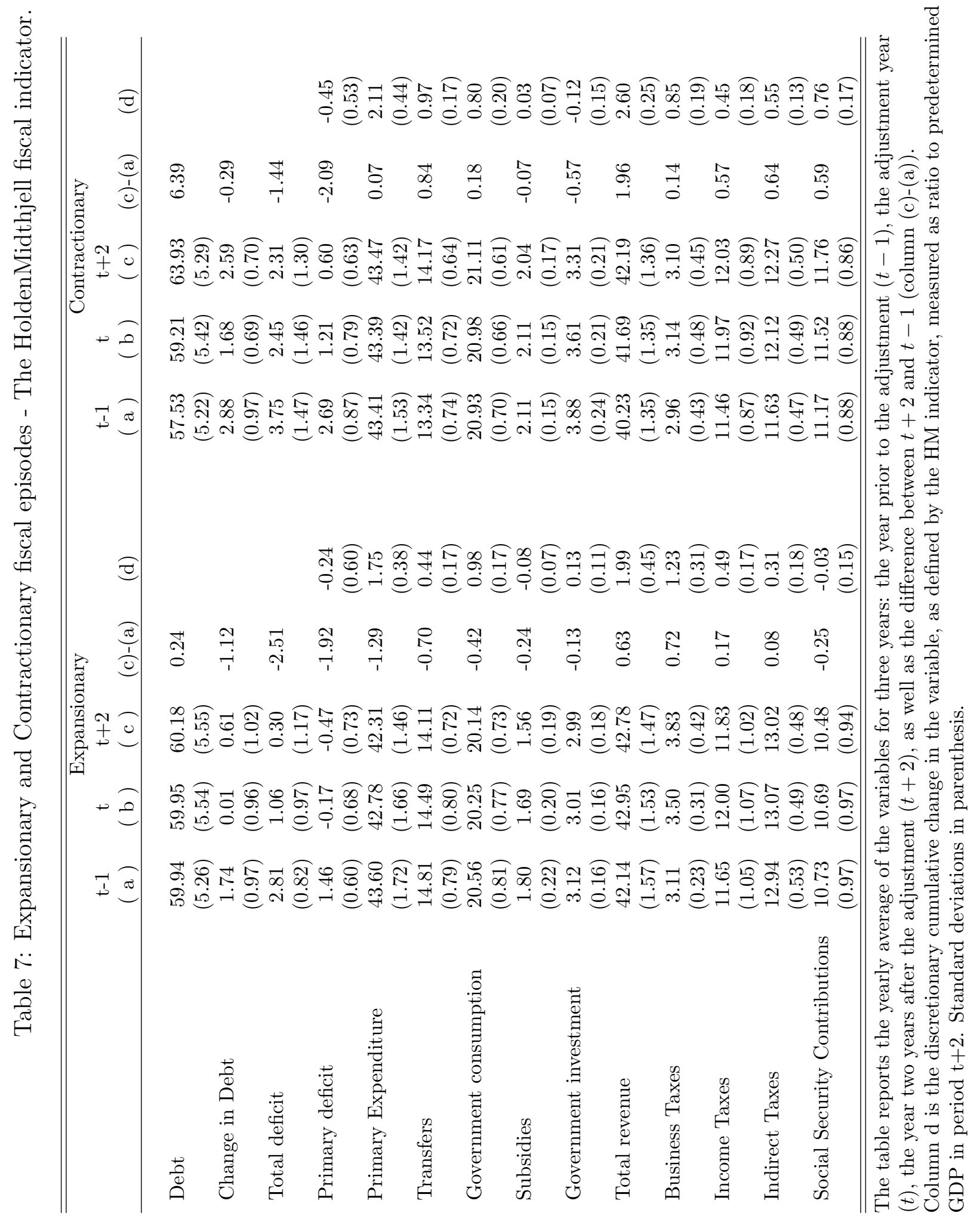


Tables 6 and 7 present the means of a number of fiscal variables across successful/unsuccessful adjustments and expansionary/contractionay adjustments respectively. Columns (a), (b) and (c) show the mean for each variable as a ratio to nominal GDP for years $t-1, t$ and $t+2$, respectively, where $t$ is the year of the fiscal adjustment. The fourth column, denoted (c)-(a), shows the difference in means between period $t+2$ and period $t-1$. We compare the actual development of the variables, as shown in column (c)-(a), with the discretionary cumulative change in the different fiscal variables, using the HM fiscal indicators as defined in Section 3.1, measured as ratios to predetermined GDP in period $t+2$ (column (d)).

The results are broadly consistent with those from the replication study in section 2.2. First, consider the results in table 6. When variables are measured as the actual change in the ratio to nominal GDP, as in Alesina and Ardagna (2010), the differences between successful and unsuccessful adjustments follow the same pattern as in their analysis. In contrast, with the HM indicator in column (d), the difference between successful and unsuccessful episodes is much smaller. While unsuccessful episodes are associated with both slightly higher tax increases and slightly higher expenditure increases than the successful ones, the difference is rather small and far from statistically significant. ${ }^{29}$ The larger increase in expenditure in unsuccessful episodes reflect a larger increase in transfers, which as noted above could also be due to reverse causality, while government consumption increases less in unsuccesful episodes. ${ }^{30}$ For revenues, social security contributions increase considerably more in unsuccessful episodes. The most noteworthy difference is that the initial budget deficit (year t-1) is considerably larger in the unsuccessful episodes. While the budget deficit on average is removed in the successful episodes ( 0.31 percent in year $t$ and -0.28 percent in year $t+2$ ), it still persists in the unsuccessful ones $(2.46$ percent in year $t$ and 2.11 percent in year

\footnotetext{
${ }^{29}$ We test for differences in means and find that except for social security contributions, for which the equal mean hypothesis is rejected at the 10 percent level, the mean differences presented in columns $d$ in table 6 are not statistically significant. For a presentation of p-values for all mean differences, see table 17 in appendix B.

${ }^{30}$ It is perhaps surprising that primary expenditure increases also during adjustments, but this reflects that we do not deduct the long run component reflecting long run growth in GDP, see the definition of the HM indicator for discretionary change in government expenditure in equation 13 above.
} 
$t+2)$. Given that the adjustments are too small to remove the budget deficit, it is not surprising that they fail to reduce debt.

The results for the effect on economic growth in Table 7 are rather similar to those for debt. With the HM indicator in column (d), the contractionary episodes are associated with both slightly higher tax increases and slightly higher expenditure increases than the expansionary ones. However, the difference is not large and, again, the higher expenditure increase in the unfavorable outcome reflects a larger increase in transfers, not in government consumption. The mean differences for transfers, investments and social security contributions are statistically significant, see table 17 in the appendix. Also here, we see that the initial deficit is higher in the contractionary episodes than in the expansionary, suggesting that this difference may also influence the outcome.

\section{Concluding remarks}

The findings by Alesina and Perotti (1995) and Alesina and Ardagna (2010) (AAP) that spending cuts are more likely than tax increases to reduce debt, have had large impact on economists' and policy makers' view on how to conduct fiscal adjustments. While there is now an increasing body of new research on this issue, the findings of AAP are likely to remain influential, due to the prominence, clarity and intuitive appeal of their methods and results.

In this paper, we argue that their results are not robust. The notable difference between fiscal adjustments that succeeded in reducing debt, and those that did not, is that the deficit on average was only removed in the former. Thus, the key policy conclusion seems to be that to reduce debt, one should adjust sufficiently to ensure that the budget deficit disappears, and not that one should use a particular instrument. In particular, one cannot use this evidence to argue against achieving debt reduction and a positive budget balance via tax rises.

Alesina and Ardagna (2010) argue that the "decision of whether or not to act on 
the spending side or the revenue side of the government is dictated by political preferences and political bargain which is, at least to a point, exogenous to the economy (..)". However, irrespective of whether the decision of spending versus revenues is exogenous, the systematic difference between successful and unsuccessful adjustment when it comes to whether the adjustment is sufficiently large to ensure a positive budget balance, clearly invalidates any conclusions on the merits of one fiscal instrument relative to the other.

We also show that the results of Alesina and Ardagna (2010), using essentially the same method as Alesina and Perotti (1995), are biased due to an imprecise measure of the change in fiscal policy. Using more precise measures of the change in fiscal policy, we do not find any clear indication that spending cuts have more expansionary effects on growth than tax rises.

\section{References}

Alesina, A. (2010). Fiscal adjustments: lessons from recent history. prepared for the ecofin meeting in madrid april 15, 2010.

Alesina, A. and S. Ardagna (2010, June). Large changes in fiscal policy: Taxes versus spending. In Tax Policy and the Economy, Volume 24, NBER Chapters, pp. 35-68. National Bureau of Economic Research, Inc.

Alesina, A. and S. Ardagna (2012, Jan-Jun). The design of fiscal adjustments. In Tax Policy and the Economy, Volume 27, NBER Chapters. National Bureau of Economic Research, Inc.

Alesina, A. and R. Perotti (1995, October). Fiscal expansions and adjustments in oecd countries. Economic Policy (10), 205-248.

Alesina, A. and R. Perotti (1996, August). Fiscal adjustments in oecd countries: Composition and macroeconomic effects. NBER Working Papers 5730, National Bureau of Economic Research, Inc.

Alesina, Favero and Giavazzi (2012, August). The output effect of fiscal consoli- 
dations. NBER Working Papers 18336, National Bureau of Economic Research, Inc.

Auerbach, A. J. and Y. Gorodnichenko (2012, May). Measuring the output responses to fiscal policy. American Economic Journal: Economic Policy 4(2), $1-27$.

Batini, N., G. Callegari, and G. Melina (2012). Successful austerity in the united states, europe and japan. Technical report, IMF Working Paper 12/190.

Biggs (2011, March). Hearing on Impediments to Job Creation. Ways and Means Committee, House of Representatives.

Blanchard, O. J. (1990, April). Suggestions for a new set of fiscal indicators. OECD Economics Department Working Papers 79, OECD Publishing.

Brooks, D. (2010, June). Prune and grow. Article in New York Times.

Caldara, D. and C. Kamps (2012). The analytics of svars: a unified framework to measure fiscal multipliers. Finance and Economics Discussion Series 2012-20, Board of Governors of the Federal Reserve System (U.S.).

Devries, P., J. Guajardo, D. Leigh, and A. Pescatori (2011). A new action-based datset of fiscal consolidation. Technical report, IMF Working Paper 11/128.

ECB (2010). Monthly Bulletin, June. Technical report, ECB.

Holden, S. and N. Midthjell (2013). A new fiscal indicator. Mimeo, University of Oslo.

IMF (2010). Will it hurt? macroeconomic effects of fiscal consolidation. In IMF World Economic Outlook. IMF.

Jayadev, A. and M. Konczal (2010, August). The boom not the slump: The right time for austerity. Available at http://www.rooseveltinstitute.org/.

Joumard, I., M. Minegishi, C. Andre, C. Nicq, and R. Price (2008, September). Accounting for one-off operations when assessing underlying fiscal positions. OECD Economics Department Working Papers 642, OECD Publishing. 
Midthjell, N. L. (2013). Successful debt reduction - a sensitivity analysis. Mimeo, University of Oslo.

Perotti, R. (2012). The austerity myth: Gain without pain? In Fiscal Policy after the Financial Crisis, NBER Chapters. National Bureau of Economic Research, Inc.

Romer, C. D. and D. H. Romer (2010, June). The macroeconomic effects of tax changes: Estimates based on a new measure of fiscal shocks. American Economic Review $100(3), 763-801$.

Romer, D. (2012). Advanced Macroeconomics. 4th Edition. McGraw-Hill.

The Tax Foundation (2013, March). Economic effects of the sequester and the proposed alternatives: What is the evidence on spending and economic growth? Fiscal Fact Nr.363.

UK HM Treasury (2009, September). International Examples of Spending Consolidations. 


\section{A Replication Analysis}

This appendix provides a more detailed account of the replication analysis. Alesina and Ardagna (2010) define a period of fiscal adjustment as a year in which the cyclically adjusted primary balance improves by at least 1.5 per cent of GDP. They find 107 fiscal adjustment years (15.1\% of the sample).

\section{Missing observations}

Given the percentages reported in the paper, the authors must have had 704 total observations of the budget balance variable out of 798 possible observations, which indicates that there are 94 missing observations. In our replica, with the same data set, and by using the same adjustment method and the same country years, we get 702 observations. We have 96 missing observations spread out in seven categories: (i) Because the series start in 1970 and we use first differences, we miss all 1970 observations (21 missing observations); (ii) For Germany, all data prior to the reunification are missing (23 missing observations); (iii) No Swiss governmental data are available prior to 1991 (19 missing observations); (iv) For Portugal, no data are available before introduction of democracy in 1978 (7 missing observations); (v) For Spain, no data are available prior to 1978 (7 missing observations); (vi) For New Zealand, no governmental data are available before 1987 (16 missing observations); and (vii) For Denmark, France and the UK, the 1971 observation is missing. ${ }^{31}$

Furthermore, the government investment variable, Gross Capital Formation, labeled $I G$ by the OECD, is missing for all years for Italy and New Zealand and we use the variable IGAA, Gross Capital Formation, Appropriation Account as a proxy. Moreover, we set the variable Social Security Contributions received by the Government, SSRG, to zero, as suggested by the Australian national budget. ${ }^{32}$

\section{Choice of fiscal adjustment years}

In our replica, we find 94 years of fiscal adjustment (13.4 percent of sample), where

\footnotetext{
${ }^{31}$ These country years are not reported in Economic Outlook Nr.84, therefore, they must have been missing for Alesina and Ardagna (2010) as well.

${ }^{32}$ Given that our results match those of Alesina and Ardagna (2010) in terms of total observations, it seems plausible to assume that they have solved these issues the same way.
} 
64 correspond to the years reported by Alesina and Ardagna (2010). Of the 43 nonmatching years, 14 lie between 1.2 and 1.5 percentage points change in the budget balance ratio, and 7 lie between 1.0 and 1.2 percentage points. An additional 8 years lie between 0.5 and 1 percentage points. 15 episodes found by Alesina and Ardagna (2010) do not match with our findings at all, and 30 of our findings do not match with the findings by Alesina and Ardagna (2010). Because we use the same definitions, data, countries, years and method for cyclical adjustment, and start out with the same amount of observations for the discretionary budget variable, it is somewhat strange that we do not get the exact same outcome. One possible explanation would be a revision in the OECD Economic Outlook 84 data base. Additionally, since we use an econometrical exercise to obtain the discretionary budget variable, the analysis is sensitive to small changes in data. In order to obtain a better comparison in episodes, we choose to include the episodes with budgetary changes between 1 and 1.5 percentage points that are reported in Alesina and Ardagna (2010) as $>1.5$. This takes us up to a total of 116 adjustment years. Table 8 provides an overview of the adjustment episodes considered in the replication analysis.

\section{Fiscal adjustment episodes}

Furthermore, in Alesina and Ardagna (2010), 65 of 107 adjustments lasted one year, 13 adjustments lasted two years, 4 adjustments lasted three years and 1 adjustment lasted four years. In our replica, we find that 58 of 116 adjustments lasted one year, 21 adjustments lasted two years, 4 adjustments lasted three years and one adjustment lasted four years. Alesina and Ardagna (2010) have chosen to define multiyear adjustments as one single episode in contrast to what was done in Alesina and Perotti (1995) where each year of adjustment counted as one episode. In a multiyear episode, the first year of fiscal change counts as the episode year. Alesina and Ardagna (2010) identify 83 fiscal adjustment episodes while, in our replica, we find 84 episodes of fiscal adjustments, 62 of which coincide with Alesina and Ardagna (2010). 


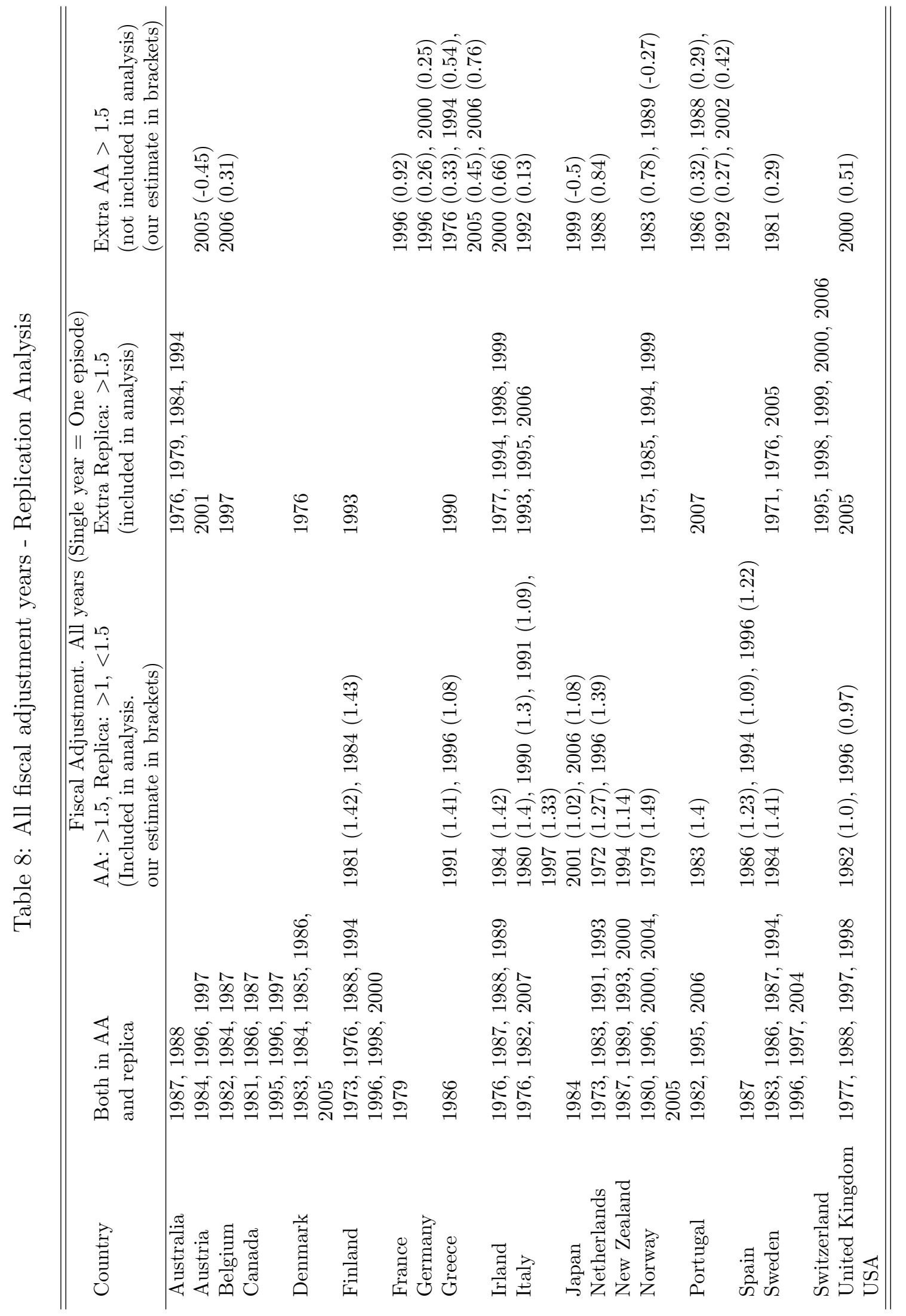




\section{Successful fiscal adjustment episodes}

Alesina and Ardagna (2010) define an episode of fiscal adjustment as successful if the cumulative reduction of the debt-to-GDP ratio three years after the first year of a fiscal adjustment episode is greater than the value of the 25th percentile of the change of the debt-to-GDP ratio empirical density in all episodes of fiscal adjustment and find the 25 th percentile to be -4.5 percentage points. For the years prior to 1980, debt data are very limited and we assume that Alesina and Ardagna (2010) use gross financial liabilities, since this series is very similar to the gross debt data in the 1980s. When using financial liabilities prior to 1980, we obtain 68 adjustment episodes (out of 84 in total) for which debt data are available. We calculate the same percentile for our dataset and find the 25 th percentile to be -5.98 percentage points. Our replication selects 16 successful episodes out of 64 possible adjustment episodes (we loose four observations due to the three-year debt window used in the definition). We find 48 unsuccessful episodes. ${ }^{33}$ Alesina and Ardagna (2010) find 17 episodes of successful fiscal adjustments. As shown in table 9, we get 9 of the 17 episodes in our replica and find 7 additional observations.

Table 9: Replication Analysis - Successful Fiscal Adjustments

\begin{tabular}{|c|c|c|c|c|}
\hline Country & Years both & Extra AA & $\begin{array}{l}\text { Years replication with } \\
\text { our debt difference of } \\
-5.98 \mathrm{pp}\end{array}$ & $\begin{array}{l}\text { Additional years } \\
\text { replication with AA } \\
\text { debt difference of }-4.5 \mathrm{pp}\end{array}$ \\
\hline Austria & & 2005 & & \\
\hline Belgium & & & 1997 & \\
\hline Denmark & 2005 & & & \\
\hline Finland & 1998 & & 1996 & 1988 \\
\hline \multicolumn{5}{|l|}{ Greece } \\
\hline Irland & & 2000 & 1994,1998 & \\
\hline Italy & 1982 & & 1997 & \\
\hline Netherlands & 1972,1996 & 1973,1993 & & \\
\hline New Zealand & & 1993, 1994 & 2000 & \\
\hline Norway & 1979,1996 & 1980,1989 & & \\
\hline Spain & & & 1986 & \\
\hline Sweden & 2004 & 1986,1987 & & \\
\hline \multirow[t]{2}{*}{ United Kingdom } & 1988 & 1977,2000 & & 1996 \\
\hline & Total 9 episodes & Total 8 episodes & Total 7 episodes & Total 2 episodes \\
\hline
\end{tabular}

\footnotetext{
${ }^{33}$ If we choose the same value for debt reduction as Alesina and Ardagna (2010), we get 18 successful and 46 unsuccessful episodes. The two additional observations, Finland 1988 and United Kingdom 1996 are not included in their paper, hence we keep our 25th percentile cut-off.
} 


\section{Expansionary fiscal adjustment episodes}

An episode of fiscal adjustment is by Alesina and Ardagna (2010) defined as expansionary if the average growth rate of real GDP, in difference from the G7 average (weighted by GDP weights), in the first year of the episode and two years after, is greater than the value of the 75th percentile of the same variable's empirical density in all episodes of fiscal adjustment. In our replica, the 75th percentile of the average growth difference variable over all fiscal adjustment episodes, not distinguishing by country equals 1,69 percent. $^{34}$ Alesina and Ardagna (2010) find 20 years of expansionary episodes (3 percent of the whole sample and 24.3 percent of all adjustment years, multiyears counted as single episodes). ${ }^{35}$ In our replica, we find 20 years of expansionary fiscal episodes (2.7 percent of the whole sample and 25 percent of the adjustment episodes). We find 60 contractionary adjustment episodes. ${ }^{36}$ Table 10 provides a comparison of the expansionary years found in this replica. Only 8 expansionary fiscal adjustment episodes coincide.

\section{Results - Full table versions}

In section 2.2 above, we argue that the results in Alesina and Ardagna (2010) are driven by reverse causality, not by choice of fiscal instrument, and provide evidence for our claim in tables 3 and 4 . Below, tables 12-11 provide the full version of the results from our replication analysis and tables 14-13 provide the full version results when we substitute GDP in the denominator of the ratios with our measure of predetermined trend GDP.

\footnotetext{
${ }^{34}$ Furthermore, Alesina and Ardagna (2010) define contractionary episodes as all episodes not being expansionary. Therefore, even if an episode is considered as contractionary, it is not necessary characterized by negative growth.

${ }^{35}$ In their paper, Alesina and Ardagna (2010) report 26 expansionary episodes, both in their table and in the text. However, as it is shown in their table, five of the reported years are subsequent years. It seems plausible that the authors mistakenly have constructed the expansionary episodes from the full sample of 107 adjustment years, and later correctly (based on what they claim in the paper) constructed successful episodes from the reduced sample of 83 fiscal adjustment episodes. The latter is not clear, however, as they correctly report 17 episodes in the text, but report 21 episodes in the table, where four episodes are subsequent years in a multiyear episode. We construct both expansionary and successful episodes from the reduced sample of multiyear episodes, not from the full sample of adjustment years.

${ }^{36}$ We lose four 2006 observations due to the way expansionary episodes are defined with three years GDP averages (Data sample ends in 2007).
} 
Table 10: Replication Analysis - Expansionary Fiscal Adjustments

\begin{tabular}{llll}
\hline \hline & & & \\
& Years Both & Extra Replica & Extra Alesina and Ardagna $(2010)$ \\
\hline Australia & & 1994 & \\
Austria & & 1996 & \\
Belgium & 1997 & 1973 \\
Finland & $1996,1998,2000$ & & $1976,2005,(2006)$ \\
Greece & & 1996 & $1976,1987,(1988,1989), 2000$ \\
Irland & 1994,1998 & \\
Italy & 1997 & $(1994)$ \\
Netherlands & 1996 & & $1979,(1980), 1983$ \\
New Zealand & 1993,2000 & 1986,1988 \\
Norway & 1996 & 1994 & $1986,(1987)$ \\
Portugal & 1995 & 1996 & 2004 \\
Spain & & 1996 & \\
Sweden & & 1998 & 18 episodes \\
Switzerland & & 1996 & \\
United Kingdom & & 12 episodes & \\
& 8 episodes & & \\
\hline \hline
\end{tabular}

Years in parenthesis are the subsequent fiscal adjustment years reported in Alesina and Ardagna (2010) 


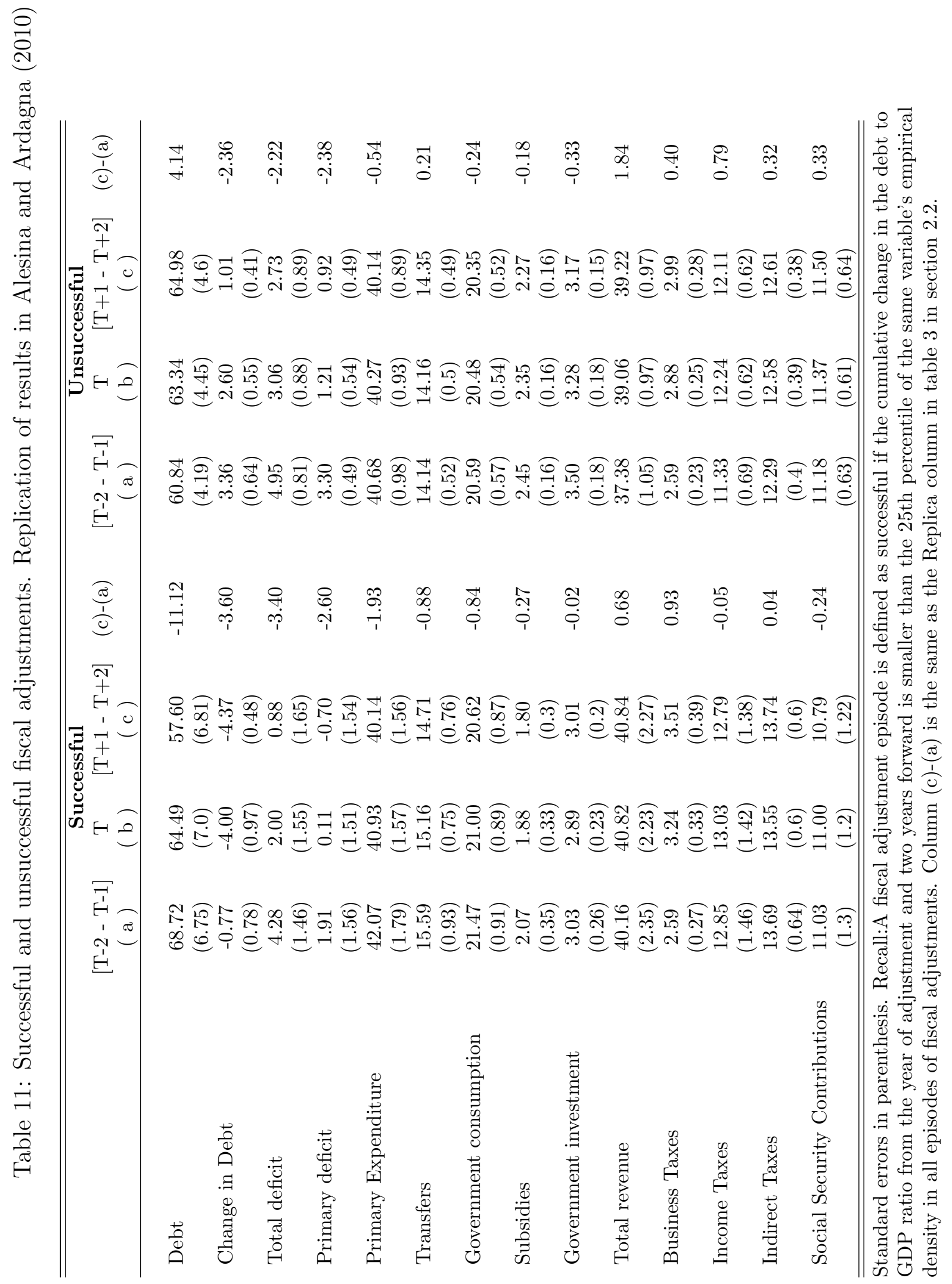




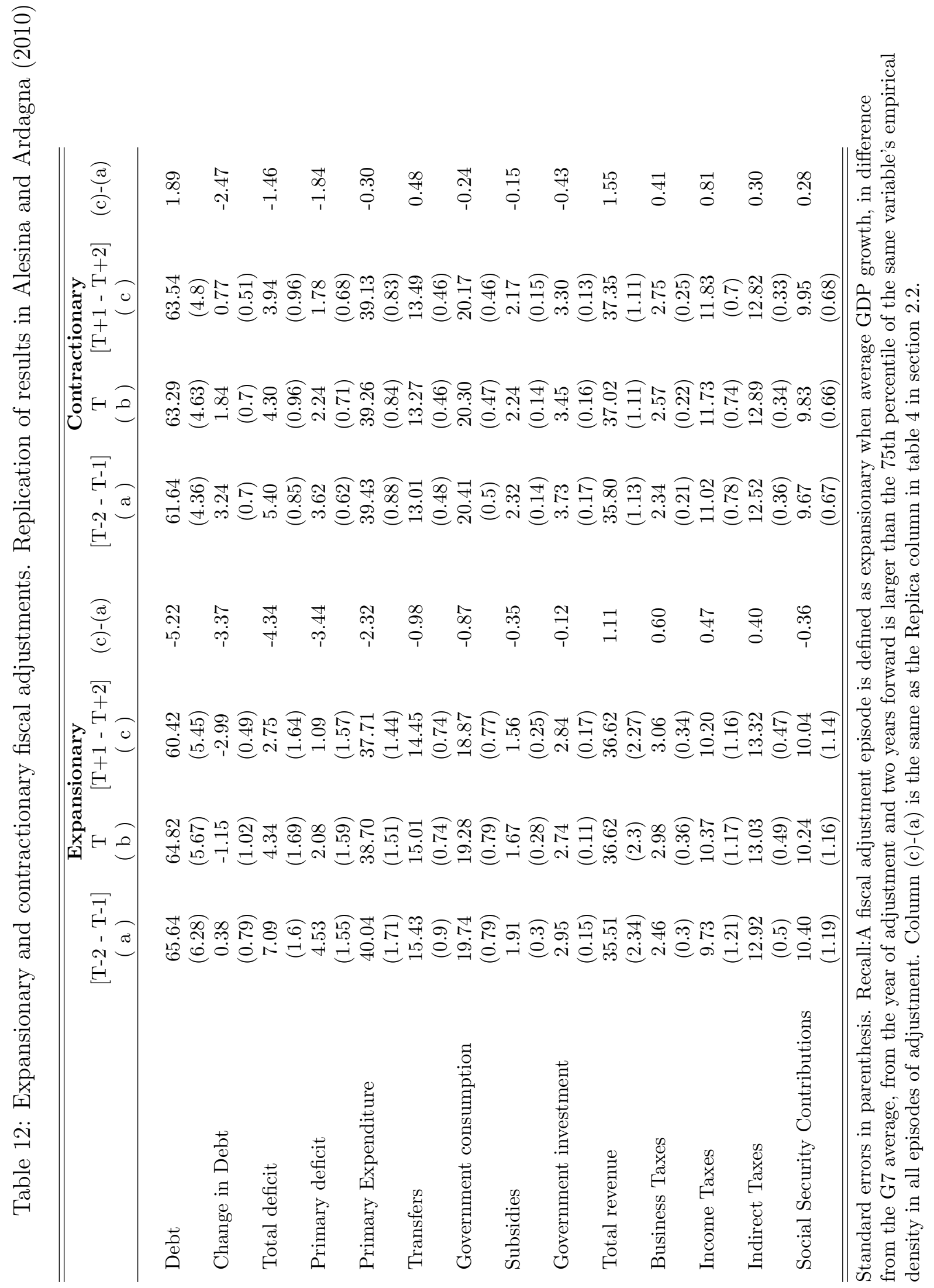




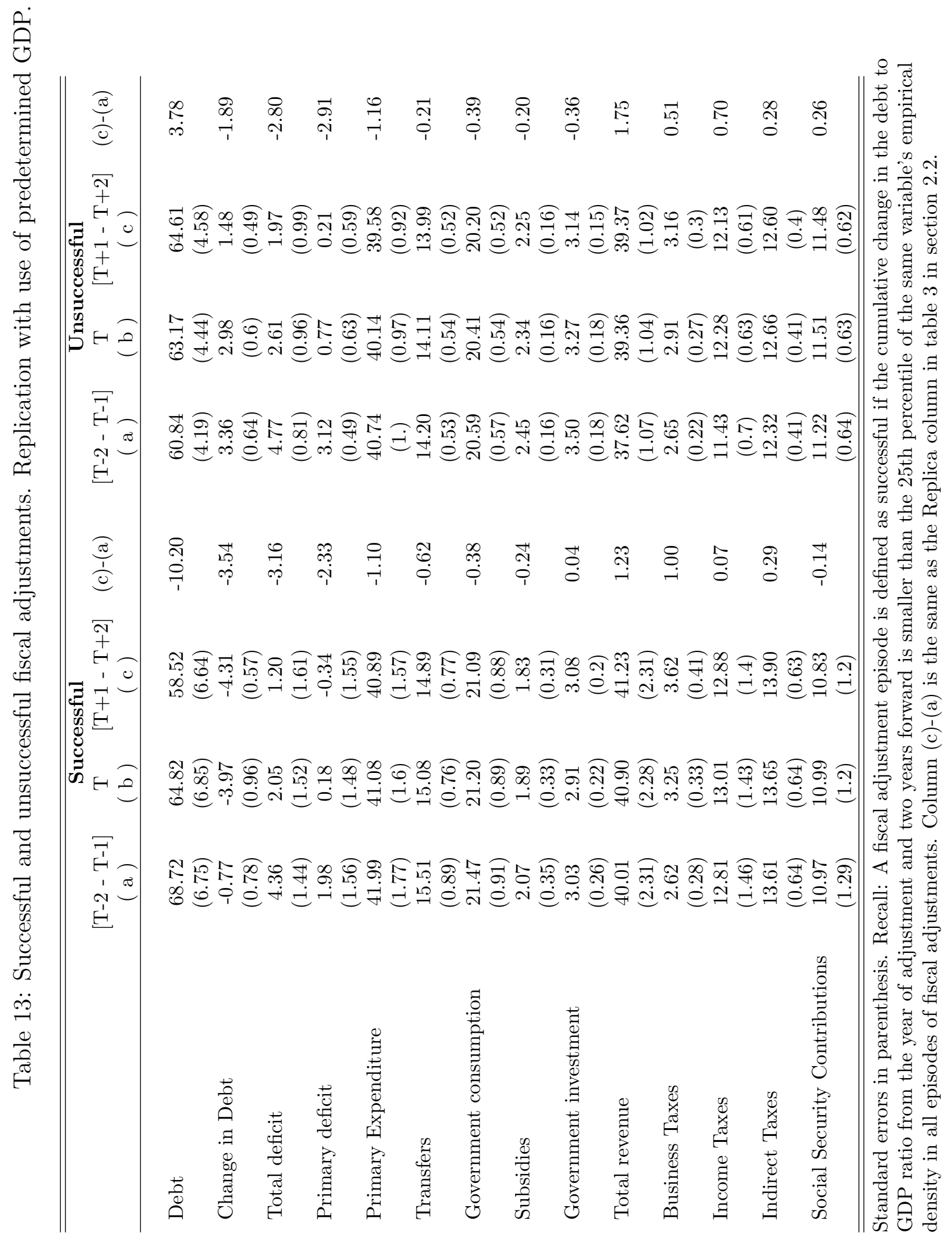




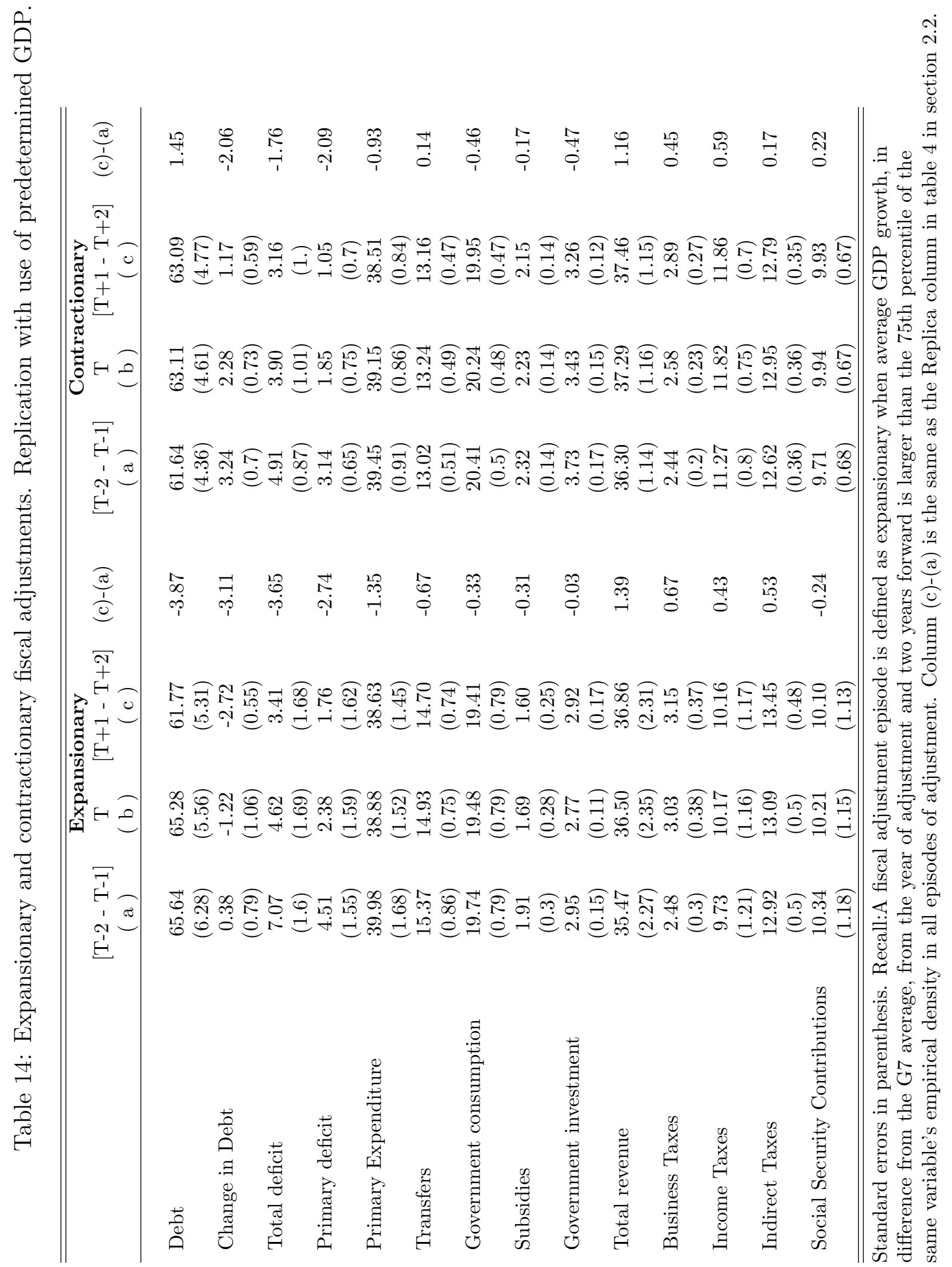




\section{B Analysis using the HM fiscal indicator}

\section{B.1 Additional tables}

Table 15: All fiscal adjustment years - The HM indicator

\begin{tabular}{|c|c|}
\hline Country & Years \\
\hline Australia & 2002 \\
\hline Austria & 1996, 1997, 2001, 2011 \\
\hline Belgium & 1977, 1982, 1983, 1984, 1993, 1994 \\
\hline Canada & $1981,1987,1995,1996,1997$ \\
\hline Czech Republic & 2010,2011 \\
\hline Denmark & $\mathbf{1 9 8 3 ,} \mathbf{1 9 8 4}, \mathbf{1 9 8 5}, \mathbf{1 9 8 6}, 1999, \mathbf{2 0 0 5}$ \\
\hline Finland & $\mathbf{1 9 7 6}, \mathbf{1 9 8 8}, 1993, \mathbf{1 9 9 4}, \mathbf{2 0 0 0}, 2011$ \\
\hline France & 1994 \\
\hline Germany & 2007 \\
\hline Hungary & 2007,2008 \\
\hline Irland & $2003,2004,2006,2011$ \\
\hline Italy & $\mathbf{1 9 8 0}, \mathbf{1 9 8 2}, 1983, \mathbf{1 9 9 0}, 1993,1995, \mathbf{1 9 9 7}, 2006$ \\
\hline Japan & 1974,1985 \\
\hline Korea & 2000 \\
\hline Netherlands & $\mathbf{1 9 8 3 ,} \mathbf{1 9 9 1 ,} \mathbf{1 9 9 3 , 2 0 0 4 , 2 0 0 5}$ \\
\hline Norway & 1995, 1999, 2000, 2004, 2005, 2006, 2008, 2010, 2011 \\
\hline Poland & $2005,2007,2011$ \\
\hline Portugal & 2006, 2011 \\
\hline Slovak Republic & 2011 \\
\hline Spain & $1992, \mathbf{1 9 9 4}, 2010,2011$ \\
\hline Sweden & 1971, 1976, 1983, 1995, 1996, 1997, 2004, 2005 \\
\hline Switzerland & 2000 \\
\hline United Kingdom & $1975,1980,2011$ \\
\hline USA & 2005 \\
\hline & 86 episodes \\
\hline
\end{tabular}

The years marked in bold are the years that coincide with the ones found by Alesina and Ardagna (2010), 34 in total. 
Table 16: Expansionary and successful fiscal adjustment episodes - the HM indicator (Bold numbers correspond to Alesina and Ardagna (2010)

\begin{tabular}{|c|c|c|}
\hline Country & Expansionary & Successful \\
\hline Australia & 2002 & 2002 \\
\hline Austria & 1996 & 1996 \\
\hline Belgium & 1993 & \\
\hline Canada & 1995 & 1995 \\
\hline \multicolumn{3}{|l|}{ Czech Republic } \\
\hline Denmark & 1999,2005 & 1999, 2005 \\
\hline Finland & $1993, \mathbf{2 0 0 0}$ & 1988,2000 \\
\hline \multicolumn{3}{|l|}{ France } \\
\hline Germany & 2007 & \\
\hline \multicolumn{3}{|l|}{ Hungary } \\
\hline Irland & 2003, 2006 & 2003 \\
\hline Italy & 1993,1997 & $\mathbf{1 9 8 2 ,} 1995,1997$ \\
\hline \multicolumn{3}{|l|}{ Japan } \\
\hline Korea & 2000 & \\
\hline Netherlands & $1991,1993,2004$ & 1993, 2004 \\
\hline Norway & $1995,1999,2004$ & 1995,2008 \\
\hline Poland & 2005,2007 & \\
\hline Portugal & 2006 & \\
\hline \multicolumn{3}{|l|}{ Slovak Republic } \\
\hline Spain & 1994 & \\
\hline Sweden & $1995, \mathbf{2 0 0 4}$ & $1995, \mathbf{2 0 0 4}$ \\
\hline Switzerland & 2000 & \\
\hline United Kingdom & & 1980 \\
\hline USA & 2005 & 2005 \\
\hline & 28 episodes & 19 episodes \\
\hline
\end{tabular}

The years marked in bold are the years that coincide with the ones found by Alesina and Ardagna (2010).

In the calculation of episodes, we lose seven adjustment episodes at the end of the sample because of the use of future variables in the definitions of expansionary and successful episodes. 
Table 17: P-values from testing for differences in means

Expansionary/Contractionary Successful/Unsuccessful

$\begin{array}{lll}\text { Primary deficit } & 0.828 & 0.528 \\ \text { Primary Expenditure } & 0.179 & 0.366 \\ \text { Transfers } & 0.008^{* * *} & 0.205 \\ \text { Government Consumption } & 0.626 & 0.833 \\ \text { Subsidies } & 0.574 & 0.538 \\ \text { Government investment } & 0.035^{* *} & 0.466 \\ \text { Total revenue } & 0.239 & 0.804 \\ \text { Business taxes } & 0.312 & 0.940 \\ \text { Income taxes } & 0.876 & 0.526 \\ \text { Indirect taxes } & 0.292 & 0.380 \\ \text { Social Security contributions } & 0.001^{* * *} & 0.077^{*}\end{array}$

$*$ significant at $10 \%,{ }^{* *}=$ significant at $5 \%,{ }^{* * *}=$ significant at $1 \%$. Null hypothesis $=$ No difference in means.

First, we test the paired variables for equal variances. Then, we run t-tests with $95 \%$ confidence intervals for differences in means for given outcome.

If unequal variance, Welch statistics is used as a robustness check. The sample for successful episodes are observed to be approximately normally distributed (for the three other variables, we consider the samples large enough to assume normally distributed means).

\section{B.2 Definition of long run component used in section 3.1}

To ensure a definition of constant policy which entails that the budget balance is constant as a ratio to GDP, we define a long run component for changes in government purchases, for category $i$, as follows:

$$
\Delta G P_{i, t}^{\text {longrun }}=G P_{i, t-1} \frac{1}{10} \sum_{k=0}^{9}\left(\Delta y_{t-k}^{\text {real }}+\Delta p_{t-k}^{\text {def }}-\Delta p_{t-k}^{\text {GPdef }}\right)
$$

where $\Delta y_{t-k}^{r e a l}, \Delta p_{t-k}^{\text {def }}$ and $\Delta p_{t-k}^{\text {GPdef }}$ is real GDP growth, GDP deflator growth and government purchases deflator growth in period $t-k$ respectively. If government purchases in real terms grow at the rate of $\Delta G P_{i, t}^{\text {longrun }}$, government purchases will be constant as a share of GDP in the long run, which seems a reasonable definition of long run constant policy. $\Delta G P_{t}^{\text {longrun }}$ denotes the sum of the long run components for consumption and investment. We define a long run component for 
the increase in transfers, $\Delta$ Trans $_{t}^{\text {longrun }}$ in the same way. 